\title{
À VOLTA DO PRINCÍPIO DA BOA FÉ
}

\author{
Raúl Guichard*
}

I. Boa fé em sentido objectivo, como regra ou norma de comportamento e critério normativo (objectivo). Distinta - ambivalência ou diferenciação já presente no direito romano - da boa fé em sentido subjectivo. Entendida esta última como estado subjectivo ou de espírito, sinónimo de ignorância de certos factos ou circunstâncias ou, dito doutro modo, uma "crença ou convicção errónea".

Tendo algumas línguas e ordenamentos inclusive uma designação diferente para a sua acepção objectiva: Treu und Glauben (fidelidade e confiança); buona fede (e corretteza); redelijheid en billijkheih; fair dealing (reservando-se good faith para o correspondente estado subjectivo, convenção porém nem sempre seguida; notar-se-á que fair dealing representa uma "aproximação mais objectiva", no sentido de lealdade como coerência e respeito pela "palavra dada" ou pelo fim contratual, possuindo uma conotação menos "moral" do que a good faith, tomada esta não na acepção subjectiva); 信義 誠実 (shingi seijitsu, boa fé, lealdade e sinceridade; quer o Art. 1, 2, do Código Civil japonês, impondo que os "direitos se exerçam e as obrigações se cumpram de acordo com as exigências da boa fé", quer o Art. 1, 3, onde se proíbe o abuso do direito, foram introduzidos pela reforma de 1947, mas o princípio da boa fé era já antes aceite e generalizado a todo o direito civil, "erigido em primeiro violino, encarregado de guiar toda a orquestra das regras do direito civil" - cfr. I. Kimatura / H. Morita / A. Omura, Rapport Japonais, in La Bonne Foi. Journées luoisiannaises, Paris, 1994, pág. 143, e Christian Förster, Das Prinzip von Treu und Glauben im japanischen Schuldrecht, Rabels Zeitschrift für ausländisches und internationales Privatrecht, 73, 1 [2009], págs. 78 e ss.].

Curiosamente, a doutrina e a jurisprudência francesas raramente estabelecem tal distinção (sendo aí também corrente a aproximação da boa fé à equidade, na continuidade do direito medieval e do direito romano - considerando no essencial a primeira como uma manifestação da segunda, Justiniano fez mesmo do jus aequum a suprema fonte do direito).

Entre nós, sugere-se falar de uma actuação segundo a boa fé por oposição a uma actuação de ou em boa fé, "estar de boa fé". Quanto a isto, à dualidade de sentidos aludida - porém, não se negará que "elementos subjectivos ou psicológicos", nomeadamente a intenção do agente, hajam de ser ponderados, mas em segunda linha, para integrar o conteúdo da boa fé objectiva, e que, simetricamente, se tenha de lançar mão de "notas objectivas" para afirmar ou negar a boa fé subjectiva - e outras distinções próximas, cfr. o nosso Da relevância jurídica do conhecimento no Direito Civil, Porto, 1996, págs. 44 e ss.

\footnotetext{
* Professor Coordenador da Área Científica de Direito do Instituto Superior de Contabilidade e Administração do Porto (ISCAP/IPP). Professor Convidado na Escola do Porto da Faculdade de Direito da Universidade Católica Portuguesa. Email: raulguichard@yahoo.es.
} 
II. No que agora interessa, a boa fé constitui um princípio (geral) normativo-jurídico. Em estreita simbiose com a ética, a moral e as concepções sociais dominantes. Como o recorda por exemplo Georges Ripert, La règle morale dans les obligations civiles, Paris, 1949, especialmente págs. 39 e ss., sobre "a moral e o contrato", e págs. 137 e ss., quanto "à justiça no exercício dos direitos", e ainda págs. 287 e ss. "Exprime a preocupação da ordem jurídica pelos valores ético-jurídicos da comunidade", diz-nos C. A. Mota Pinto.

Fala-se, neste contexto, da sua "função moralizadora" (de promoção de uma "nova moralidade contratual", embora não imponha, costuma juntar-se, que se viva no "reino da virtude", muito menos nos nosso tempos de "recuo da moral"; ver apenas Didier Krajeski, Les outils jurisprudentiels de la moralisation, in Libre droit. Mélanges en l'honneur de Philippe le Tourneau, Paris, 2008, págs. 563 e ss.). Assim, entre muitos, Rodolfo Sacco, La trattativa, in Trattato di Diritto Civile (diretto da Rodolfo Sacco), II contratto, II, Torino, 2004, pág. 233.

Em todo o caso, um critério intra-jurídico (não um valor meta-jurídico, como a caritas, ou o bem-estar social ou o bem comum ou a utilidade social, conforme acentua F. Wieacker; o autor lembra ainda as reservas e censuras formuladas - mormente por Hedemann, Ripert e, mais tarde, Boehmer, a que se juntará Rüthers - às cláusulas gerais, concebidas como um reenvio ou uma "fuga" para critérios extra-jurídicos, tornadas assim insusceptíveis de constituírem uma verdadeira medida e linha directriz da solução do caso concreto, representando antes uma porta aberta para a arbitrariedade e, em particular, para o jogo dos interesses políticos]. A componente ético-jurídica surge mesmo em primeiro plano no princípio da boa fé; diversamente no princípio da confiança avulta também (inseparavelmente) um elemento orientado para a protecção da segurança ou certeza do tráfego jurídico. Cfr. introdutoriamente Karl Larenz, Richtiges Recht. Grundzüge einer Rechtsethik, München, 1979, págs. 85 e ss.

Para uma inicial delimitação em relação aos "bons costumes", que se reportarão às "exigências mínimas" que, de acordo com os critérios ético-sociais amplamente aceites, a todos são colocadas na vida em comum sob o direito - enquanto o conteúdo do princípio da boa fé, também constituindo uma "ponte de conexão entre o direito e as convicções gerais", irá bem além disso, "condensar-se-á", porquanto suporia uma "relação especial" entre as partes interveniente e, por conseguinte, um certo grau ou limiar de confiança e de disponibilidade para uma actuação comum ou recíproca leal -, ver do autor antes citado, Lehrbuch des Schuldrechts, I, Allgemeiner Teil, München, 1987, págs. 128 e s.

III. Um princípio (e "regra disciplinadora", por isso não carecendo de ser invocada, de aplicação ex officio) central, nuclear, cardinal [e "pervasivo"] no nosso sistema. E com carácter imperativo (subtraído à disposição das partes - cfr. Art. 1:201 PECL; no entanto, não se falará de inderrogabilidade se com isso se quer significar não poderem de modo nenhum as partes fixarem o critério de apreciação das suas condutas futuras e excluírem quaisquer, da boa fé decorrentes, complementações e restrições dos seus direitos - a maioria dos quais será aliás disponível].

Mutatis mutandis, o mesmo se poderá dizer para a maioria dos ordenamentos europeus da civil law (e ainda para vários "sistemas mistos ou híbridos"). De um revival da boa fé e do seu brilhante porvir (outros são menos optimistas...) fala-se até (desde umas décadas atrás).

Porventura, com fundamento constitucional (questão diferente, mas conexa, prende-se com o entendimento recorrente de que o princípio da boa fé é um meio de "penetração" ou de "permeabilização", "porta de entrada" (Einfallstor) ou "ponto de osmose", no direito privado, dos 
valores e princípios constitucionais].

Princípio que mostra "um imenso potencial jurigénico" (C. A. Mota Pinto), um "poderoso conceito” (H. L. MacQueen), "omnipresente”. Alcança toda a vida jurídica, invade todos os campos (nem se vê que seja necessário a concreta identificação de uma vinculação jurídica, como pretendem certos autores). Abrange cada um dos ramos do direito (material e processual entre nós, no Código do Processo Civil, cfr. arts. 266. ${ }^{\circ}, 266 .^{\circ}-\mathrm{A}, 266 .^{\circ}-\mathrm{B}$ e, sancionando a má fé processual, art. 456. ${ }^{\circ}$; na doutrina, para este último domínio, ver apenas o excelente livro de Joan Picó i Junoy, El principio de la buena fe procesal, Barcelona, 2003).

Atravessa e enforma também o direito público e constitucional. Basta pensar na crescente importância da ideia de confiança e da respectiva tutela no comportamento (futuro) do legislador. Tenha-se ainda em conta a vinculação da Administração Pública ao princípio da boa fé, nos termos do art. 266. ${ }^{\circ}$, n. ${ }^{\circ} 2$, in fine, da Constituição da República Portuguesa (no recentissimamente revisto Código do Procedimento Administrativo, veja-se o Artigo $10{ }^{\circ}$ Princípio da boa-fé 1 - No exercício da atividade administrativa e em todas as suas formas e fases, a Administração Pública e os particulares devem agir e relacionar-se segundo as regras da boa-fé. 2 - No cumprimento do disposto no número anterior, devem ponderar-se os valores fundamentais do Direito relevantes em face das situações consideradas, e, em especial, a confiança suscitada na contraparte pela atuação em causa e o objetivo a alcançar com a atuação empreendida) e ainda o Artigo 11. ${ }^{\circ}$ Princípio da colaboração com os particulares 1 - 0s órgãos da Administração Pública devem atuar em estreita colaboração com os particulares, cumprindo-lhes, designadamente, prestar aos particulares as informações e os esclarecimentos de que careçam, apoiar e estimular as suas iniciativas e receber as suas sugestões e informações. 2 - A Administração Pública é responsável pelas informações prestadas por escrito aos particulares, ainda que não obrigatórias].

Vigorando no próprio direito internacional público, como regra consuetudinária jurisprudencialmente reconhecida (cfr., precursoramente, o acórdão do Tribunal Permanente de Justiça Internacional de 25 de Maio de 1926, Interesses alemães na Alta-Silésia polaca, CPJI, série A, n. ${ }^{\circ}$ ?, págs. 30 e 39). E consagrada expressamente no domínio do direito dos tratados, na sua negociação, interpretação e execução (cfr. art. $18 .^{\circ}$, art. $31{ }^{\circ}$ e art. $26 .{ }^{\circ}$ da Convenção de Viena de 1969).

Passando ao direito comunitário, registe-se apenas que os arts. $4 .{ }^{\circ}, \mathrm{n} .{ }^{\circ} 3$, e $13 .{ }^{\circ}, \mathrm{n} .{ }^{\circ} 2$, do Tratado da União Europeia instituem o princípio da cooperação leal, no quadro das relações entre a União Europeia e os Estados-Membros e das Instituições, e impõem, mais especificamente, aos Estados-Membros que tomem "todas as medidas gerais ou específicas adequadas para garantir a execução das obrigações decorrentes dos Tratados ou resultantes dos actos das instituições da União" e que "facilit[e]m à União o cumprimento da sua missão e [se abstenham] de qualquer medida susceptível de pôr em perigo a realização dos objectivos da União - o que pode ser visto como transposição para esse âmbito do princípio internacional da protecção da confiança legítima e, como seu corolário, do princípio da boa fé, portanto como um "reforço de uma preexistente obrigação", e ainda como "método de interpretação sistemática". Tais disposições, inicialmente encarados como meras normas interpretativas, lançando luz sobre as obrigações específicas inerentes aos Tratados, são hoje vistas como fonte autónoma de obrigações, susceptível de conduzir a um "processo formal por infracção", nos termos do Art. $258 .^{\circ}$, como o reiterou, por último, o Acórdão do Tribunal de primeira Instância [Primeira Secção], 17 de Janeiro de 2007, no processo T-231/04, República Helénica contra Comissão 
das Comunidades Europeias]. Diga-se ainda que, segundo jurisprudência constante do Tribunal do Tribunal de Justiça, a Administração de cada Estado está vinculada ao princípio da boa fé, independentemente de actuar nos termos do direito público ou do direito privado. 0 recurso a tal critério assume particular importância na falta de uma norma comunitária e na inviabilidade de recurso a uma norma de direito interno. E também a relação de trabalho ou serviço público está submetida ao mesmo princípio (daí se extraindo importantes corolários, nomeadamente quanto à sua cessação). Mencione-se, por último, que em vários acórdãos o Tribunal lançou mão praeter legem do princípio da boa fé na interpretação-aplicação de disposições de vários Tratados. Tome-se como ilustração a Convenção de Bruxelas de 1968 (Convenção relativa à competência judiciária e à execução de decisões em matéria civil e comercial), designadamente em matéria de acordos de extensão de competência (e respectiva forma). Já no direito comunitário secundário, a referência ao princípio da boa fé é recorrente. Isso, mormente em matéria contratual. Exemplo representativo é a Directiva 93/13/CEE do Conselho, de 5 de Abril de 1993, relativa às cláusulas abusivas nos contratos celebrados com os consumidores. Sem que, porém, no direito europeu dos contratos se possa ver plasmado como princípio geral; apenas se encontrando pontuais regulamentações susceptíveis de serem encaradas como imposições de um comportamento leal em certas situações ou como concretizações parcelares da ideia da boa fé. Em todo o caso, o Tribunal de Justiça reconhece que o direito comunitário não se opõe a que os órgãos jurisdicionais nacionais apliquem uma disposição de direito nacional consagrando o princípio da boa fé ou uma sua materialização (nomeadamente a figura do abuso de direito] a fim de apreciar o exercício de um direito decorrente duma disposição comunitária (saber, por exemplo, se ele foi exercido de maneira abusiva - ver Acórdão do Tribunal de Justiça, 12 de Maio de de 1998, processo C-367/96, Kefalas]. Cfr., sobre estes aspectos aqui apenas aflorados, Karl Riesenhuber, System und Prinzipien des Europïschen Vertragsrecht, Berlin, 2003, págs. 398 e ss.

A boa fé impera, claro, na inteira área privatística civilística (direito contratual, direito da propriedade, direito da família e das sucessões]. Exemplarmente, a este propósito, a consagração legal da boa fé ou da honestidade e credibilidade, 诚实信用, como princípio geral do direito civil chinês. A par, de resto, com o princípio da "voluntariedade", "voluntarieness", 自愿, grosso modo a ideia de autonomia privada (que no entanto há de ser entendida à luz dos traços de uma economia centralizada e planificada que subsistem - cfr. aliás Art. 6, Art. 7 e Art. 58(6) dos Princípios Gerais do Direito Civil chinês], Art. 7 da Lei dos Contratos chinesa. Com o princípio da justiça ou lealdade ["fairness"], 公平, e com princípio da "comutatividade", "equilíbrio de prestações" ou “making compensation for equal value”, 等价有偿 - Art. 4 dos Princípios Gerais do Direito Civil chinês. Princípios depois concretizados (com excepção da comutatividade que de algum modo se verá assegurado no princípio da igualdade ou igual posição das partes traduzido no Art. 3] para o direito contratual nos Arts. 3 e ss., 42 e 60 da Lei dos Contratos chinesa, proclamando-se nomeadamente o princípio da boa fé no exercício dos direito e no cumprimento das obrigações, incluindo na fase pré contratual.

Em particular, perpassa a boa fé todo o âmbito obrigacional ou negocial (não se vê porque excluir de antemão os negócios unilaterais]. É dita "a alma dos contratos".

Sendo até encarada, pelo menos neste domínio, como critério supremo, superior aos demais; ideia, porém, a entender cum grano salis, indicando-se a necessidade da sua contemporização com o princípio da autonomia privada, com o qual estará em "permanente diálogo e contraponto". Com efeito, antecipando o que melhor se assinalará adiante, a aplicação do prin- 
cípio da boa fé, sobretudo na sua "função correctiva" (representando um "Überdruck ventil", "uma válvula de escape"], conhece certos limites, seja decorrentes do princípio da autonomia privada, seja principalmente em áreas de direito estrito onde a observância rigorosa e segura dos pressupostos e das cominações legais se imponha, sobretudo por razões de certeza, como sucede em matéria de prazos ou de injunções de forma, designadamente quanto ao formalismo do testamento e do casamento (nestes termos, por exemplo, K. Larenz, op. cit., pág. 130). Para os PECL, fala-se dos três lados ou segmentos do triângulo contratual, compreendendo a boa fé, a liberdade negocial e a certeza ou segurança jurídica (a imagem colhe-se em Principes du droit européen du contrat [Version française préparée par Georges Rouhette, avec le concours de Isabelle de Lamberterie, Denis Tallon, Claude Witz], Paris, 1977, pág. 19]. E veja-se aí o Art. 1:106, onde se estabelece que a interpretação e a integração dos PECL se há-de fazer atendendo à "necessidade de favorecer a boa fé, a segurança das relações contratuais e a uniformidade da sua aplicação".

Se se quiser salientar, na sua incidência, uma fase do iter obrigacional, mencionar-se-á o cumprimento ou a execução das obrigações das partes [a esse propósito - execução das "conventions" - o menciona, de resto, o Código de Napoleão no seu Art. 1134, 3, preceito que muito contribuiu para a difusão e positivação do princípio nas ulteriores codificações civis europeias].

IV. Contudo, ordenamentos existem, como o inglês (e islandês ou, de um modo geral, a commom law; mas ver o que adiante se diz) que sobrevivem sem, no essencial, reconhecerem um dever geral de proceder de boa fé. No sucinto mas claro dictum, muitas vezes citado, de Bingham LJ: "English law has characteristically committed itself to no such overriding principle [but has developed piecemeal solutions in response to demonstrated problems of unfairness]". Desde logo, também na fase pré-negocial ou, mais em geral, no âmbito contratual.

Todavia, não se resiste a observar, a esta última área havia-a confinado o direito romano, constituindo aí um específico instrumento para os contratos consensuais. Ainda hoje - não é também sem interesse referi-lo - em certos ordenamentos, o "campo de operação" da boa fé tende a ser circunscrito às relações contratuais, como ocorre no ordenamento francês, quanto à aplicação do disposto no Art. 1134, 3, Code Civil, segundo a orientação da Cour de Cassation (de resto, mesmo neste domínio numa utilização mais contida do que a da experiência germânica - isso conduz à curiosa constatação comparatística de que nem sempre a previsão expressa ou específica de um princípio ou de um instituto, mesmo que em termos relativamente gerais ou latos, conduz a uma sua aplicação mais generalizada ou intensa).

0 direito inglês rejeita, portanto (e não obstante "certos paliativos" ou "importantes sucedâneos" - consoante os autores -, como o uso das figuras da misrepresentation, do promissory estoppel, do estoppel by aquiescence, a intervenção das regras do enriquecimento sem causa, a noção de "contrato colateral", a aplicação do direito dos torts, o tratamento especial dos contratos uberrima fides], uma "materialização" da liberdade negocial, pelo menos comparável à praticada na civil law.

Em razão de um postulado liberal e das exigências do sistema económico de mercado. Arrimado num modelo voluntarístico ou individualístico das relações jurídicas, contratuais, herdado da tradição mercantil (aqui se insere um forte pendor subjectivista quanto à interpretação, embora com amplo recurso aos implied terms]. Recusando, por regra, a ingerência da moral na esfera jurídica: "the purpose of legislation should not be to make a moral demonstration". Tendo por detrás uma acerada preocupação com a certeza e segurança, com a previsibilidade 
das relações jurídico económicas e, concretamente, o temor da eventual incerteza e discricionariedade judiciais introduzidas por uma "construção de contornos não suficientemente definidos". Apontando-se, em especial, que a atribuição de um papel completivo ou integrativo à boa fé (não meramente excludente ou restritivo, sancionando um comportamento de má fé ou banindo uma cláusula contrária à boa fé), servindo até para criar obrigações suplementares e modificar o conteúdo contratual, desnaturaria a própria noção daquela.

Haverá talvez que perguntar se tal cepticismo em face do princípio da boa fé - "la bête noir des juristes anglais", mas a "pièce de résistance" dos juristas continentais em matéria de princípios contratuais - não resulta afinal de um diferente modelo de contrato e de uma "matriz antagonista" da contract law. Assente esta numa adversarial ethic, avessa ou menos receptiva a um dever geral de cooperação, surgindo a boa fé afinal como um "legal irritant", para nos socorrermos da expressão de G. Teubner. Na observação de Lord Ackner: "the concept of a duty to carry negotiations in good faith is inherently repugnant to the adversarial positions of the parts involved in negotiations".

A common law tão-pouco aceita uma responsabilidade geral com base na culpa in contrahendo, com fundamento no princípio geral da boa fé. Nem se socorre deste para admitir a cláusula rebus sic stantibus. Embora nas situações em causa, para além da eventual previsão pelas partes de "cláusulas de hardship", possa intervir a figura da frustration of the contract, vindo-se a fundar então a possibilidade de desvinculação numa cláusula negocial implícita.

Porém, como se deu a entender, o não reconhecimento (geral) do princípio da boa fé, em especial na área negocial, não vale para todos os ordenamentos da família da common law.

Assim, no direito estadunidense, o Restatement Second of Contracts (mas isso não sucedia no Restatement First) impõe um dever geral de boa fé no domínio contratual - § 205, Duty of good faith and fair dealing: Every contract imposes upon each party a duty of good faith and fair dealing in its performance and its enforcement. Por outro lado, o Uniform Comercial Code (2001) define explicitamente a boa fé no seu § 1-201: Good faith means honesty in fact and the observance of reasonable commercial standards of fair dealing. Acrescentando-se no $\S 1-304$ (Obligation of Good Faith): Every contract or duty within the Uniform Commercial Code imposes an obligation of good faith in its performance and enforcement. E realçando-se o seu carácter imperativo - § 1-302 (Variation by Agreement): Except as otherwise provided in subsection (b) or elsewhere in [the Uniform Commercial Code], the effect of provisions of [the Uniform Commercial Code] may be varied by agreement. (b) The obligations of good faith, diligence, reasonableness, and care prescribed by [the Uniform Commercial Code] may not be disclaimed by agreement. The parties, by agreement, may determine the standards by which the performance of those obligations is to be measured if those standards are not manifestly unreasonable. Demais, na fase pré-contratual é corrente, operar-se aí com a "foregone opportunities theory", segundo a qual, durante o período de formação dos contratos, as partes renunciam à oportunidade de celebrarem outros acordos colidentes ou inconciliáveis com 0 negócio em preparação, constituindo uma conduta de má fé a tentativa de se reapropriarem dessa oportunidade renunciada.

No direito canadense, também se deu uma evolução similar (jurisprudencial; mas veja-se o Art. 1375 do Código Civil do Québec]. Um marco é a recente decisão Bhasin v. Horynew [2014 SCC 71], no qual o Justice Cromweel, o relator, escreveu: "In my view, it is time to take two incremental steps in order to make the common law less unsettled and piecemeal, more coherent and more just. The first step is to acknowledge that good faith contractual performance 
is a general organizing principle of the common law of contract which underpins and informs the various rules in which the common law, in various situations and types of relationships, recognizes obligations of good faith contractual performance. The second is to recognize, as a further manifestation of this organizing principle of good faith, that there is a common law duty which applies to all contracts to act honestly in the performance of contractual obligations". Algo semelhante se poderá dizer para o direito escocês (embora este se deva ter como um sistema misto ou híbrido]. E para os direitos de alguns países nórdicos [agora, claramente, fora da common law), onde a jurisprudência parece ter evoluído nesse sentido, conquanto sem base legal.

V. Já nos ordenamentos continentais europeus, a boa fé (em sentido objectivo) apresenta-se, normalmente, na forma de uma cláusula geral - dita até, pelo seu alcance genérico, a "cláusula rainha", "Königsregel", o "parágrafo régio" [formulações algo associadas, é certo, ao pensamento ou ideologia da Escola do direito livre no seu louvor às cláusulas gerais, as quais corroborariam decorrer a decisão judicial afinal do sentimento jurídico e da razão prática do aplicador). Surge como uma "norma aberta" (e, portanto, "atípico" o seu conteúdo normativo, conforme se costuma destacar na doutrina italiana; fugindo assim a uma definição, cujo perímetro não pode ser estabelecido em abstracto] ou "elástica", com alto grau de abstracção, aplicável a muito diferentes hipóteses, não predetermináveis e de configuração polimorfa ou proteiforme, ostentando "mantos" caleidoscópicos, policromos (não como uma "rule"; embora tal não desminta a sua "imediata validade ou intenção aplicativa" e "conteúdo próprio", tão-pouco devendo, vê-lo-emos ainda à frente, ser encarada como uma "Leerformel", ou como uma "Blankettnorm", uma mera "Normbildungermächtigung", como uma "varinha de condão" que logo permita obter a solução tida por desejável, ou como uma "norma programática"]. Já Heck lembrava neste contexto, a propósito da evolução do direito das obrigações, o mito da luta entre Menelau e Proteu. A "bonne foi caméléon", no dizer Y. Loussouarn.

E insusceptível, como se compreende, de imediata subsunção. Carecida antes de concretização e mediação. Quer quanto às hipóteses sobre que incidirá, quer quanto às consequências decorrentes da sua violação (daí por vezes se falar numa "dupla cláusula geral"). Assim, a mero título de exemplo, e como melhor se aludirá adiante, pense-se na sua particular incidência nos "contratos relacionais" - para recorrer à conhecida noção desenvolvida por L. R. Macneil. Ou nas muito variadas sanções de uma actuação desleal, nas diferentes consequências da violação de uma confiança legítima suscitada na contraparte ou, mais em geral, de deveres decorrentes da boa fé, a saber: a inadmissibilidade de determinado exercício de um direito ou faculdade; a invalidade ou ineficácia do contrato ou de uma cláusula a este pertencente ou a possibilidade da sua resolução ou distrate; a concessão de uma pretensão indemnizatória, seja pelo interesse negativo, seja pelo interesse positivo; a eventual influência sobre o conteúdo do contrato ou relação; a imposição de um dever de renegociação; o surgimento de uma obrigação de não-concorrência.

E necessitando de preenchimento valorativo (recurso a juízos de valor), para ser aplicada a situações concretas, havendo que ponderar extensa e profundamente os específicos interesses dos intervenientes e as concretas circunstâncias do caso (à luz da ideia fundamental orientadora).

Sem que com isso, insistimos, se autorize o estrito recurso - ou a sua recondução, renunciando a precisá-la do ponto de vista dogmático, não se estabelecendo a ligação na sua aplicação "com os pensamentos jurídicos gerais que traduz" - à equidade (não se negando que também 
a boa fé, na sua "função correctiva", serve para alcançar a "justiça do caso concreto" e conflituará com a segurança e certeza jurídica - mas precisamente, por isso, nesse "nível" da sua aplicação, impor-se-ão particulares exigências e cautelas, não podendo desembocar numa "allgemeine Billigkeitsjustiz"). Ver todavia a referência à "équité", feita no Art. 1135 do Code Civil; havendo ainda que apontar que Domat nas suas Lois civiles emprestava comummente a boa fé um sentido sinónimo de equidade, encontrando a sua justificação ou emanando da noção de "direito natural". Mais em geral, sobre as funções correctiva e supletiva - porventura similares e concorrentes com as da boa fé - da equidade no direito privado, cfr. Christophe Albiges, De l'équité en droit privé, Paris, 2000; e sobre as relações históricas entre os dois conceitos, além do que já se anotou, Thomas Duve, § 242. Leistung nach Treu und Glauben, in Historische-kritischer Kommentar zum BGB, II, Tübingen, 2007, págs. 280 e ss.

Menos ainda se deverá transformar a boa fé num "biombo retórico" (banalizando a sua invocação, por vez das pertinentes e específicas disposições legais, numa "fuga para a cláusula geral"); num cavalo de Tróia do subjectivismo interpretativo; numa porta aberta ao casuísmo ou a orientações meramente tópicas; se se quiser, na justiça do Cádi ou na transmutação do juiz em legislador; num modo de irrupção de valorações irracionais (não persuasivamente fundamentadas). Com o que se resvalaria para o arbítrio, se pisaria um terreno movediço. Representando aquela uma fonte de insegurança e incerteza intolerável (para os destinatários). Num singelo exemplo, o facto de o exercício de um direito pelo seu titular se traduzir numa vantagem diminuta para ele, embora com consequências molestas ou gravosas para outrem, não significará, só por si, uma violação da boa fé.

Elucidativo, em geral, sobre a necessidade de o direito assentar em regras simples e formais, que estabeleçam claramente os limites ou o enquadramento dos comportamentos admissíveis, e não num "difuso sentimento geral" ou na pessoal mundividência, cfr. já Max Weber, Wirtschaft und Gesellschaft, Tübingen, 1922 (escrito entre 1911 e 1913), págs. 503 e ss. (capítulo sobre as qualidades formais do direito moderno); e, bem mais recentemente, os vários escritos de Richard A. Epstein, por último The Optimal Complexity of Legal Rules, in http://www. law.uchicago.edu/files/Epstein optimal com plexiypdf.

Donde a necessidade de "sedimentação" ou "precipitação" da boa fé em critérios, conceitos ou figuras ["sintomáticas"], formas ou moldes de argumentação mais específicos, porventura "sub-princípios" mediadores ou concretizadores. Muitos destes com assento na lei. Cujas decisões valorativas ou ponderações o intérprete tem de respeitar.

Mais: normalmente, a boa fé assume um papel subsidiário. E a sua "directa aplicação" surgirá como uma última e não banal instância ou recurso, ultima ratio, uma vez "esgotadas as possibilidades técnicas do sistema" (na expressão de Rui de Alarcão).

Além disso, frise-se a necessidade de a "precisar", por parte da doutrina e da desenvolução judicial (semelhantemente ao case law anglo-saxónico), pelo desglosamento ou discriminação de vários parcelares "domínios funcionais" ["Funktionskreisen"] e pela identificação ou formação de "grupos ou constelações de casos" ["Fallgruppen").

Sendo necessário a sua tipicização, à volta de sub-princípios, e a individualização de figuras munidas de autonomia conceptual, desembocando - seguindo mas ao mesmo tempo guiando o seu desenvolvimento - num "sistema interno" ou, na expressão de J. Schmidt, num "Binnensystem". 0 qual, no entanto, como ainda se previne, não deve evoluir para a "fossilização", converter-se num "cânone fechado", tornando a boa fé num "strait jacket", envolver um retorno geral a regras específicas, sendo o resultado final obtido a sua rigidificação, o chamado "efeito 
engessamento", contraditório com o próprio conceito ou a função de uma cláusula geral.

Ademais, como aflorado, o princípio da boa fé (como a generalidade dos princípios - recorde-se aqui a observação de R. Dworkin de que os princípios "caçam aos pares") há-de ser contemporizado, numa tarefa de "concordância prática", com outros princípios e valores, designadamente com o da autonomia privada. Nesse sentido, veja-se especialmente o que adiante se expõe quanto ao pensamento de Canaris.

Paradigmaticamente, apontar-se-á a necessidade de a conciliar com a liberdade negocial na fase pré-contratual, onde justamente ainda não existe um vínculo e cada parte tende legitimamente a prosseguir, maximizar, o interesse próprio - sobretudo a respeito do tratamento das hipóteses de interrupção das negociações e da imposição de deveres de esclarecimento e deveres de informação (omitida fica aqui uma descrição dos principais tipos de deveres pré-contratuais, atinentes quer ao próprio negócio, quer respeitantes a bens jurídicos estranhos àquele, nomeadamente dos deveres de lealdade, dos deveres de cooperação, dos deveres de protecção ou cuidado - e, dentro destes últimos ou porventura autonomizados mas com carácter mais específico, dos deveres de guarda e custódia, do dever de reserva ou segredo ou de confidencialidade -, e dos deveres de informação - os que nessa fase mais avultam, cuja consagração legal em certos domínios está em franca expansão, e que conhecem caracterizações diversas, conteúdos também distintos, importando a sua violação consequência igualmente diferentes, em parte, claro, função de o contrato se ter celebrado ou não e de ser ou não válido). Ou de a harmonizar com o princípio pacta sunt servanda (onde se trate de alterar ou pôr término a um contrato por alteração superveniente das circunstâncias]. Ou mesmo de a temperar com princípio da relatividade dos contratos, privity of contract.

Ver ainda, para este ponto, K. Larenz / C.-W. Canaris, Methodenlehre der Rechtswissenschaft, Berlin, 1995, págs. 302 e ss., aludindo também à necessidade de concretização mediante sub-princípios e ao problema da "compatibilização" e "jogo" entre os vários princípios.

Do "carácter (extremamente) aberto" da boa fé também decorre, como afirmado, a exigência de não a converter num "varinha de condão" (logo permitindo obter o resultado que se julga desejável em qualquer caso], a necessidade de conter a sua aplicação dentro de certas balizas, de "manter a caixa de Pandora fechada", de não abrir a Porta Pandana, que deve permanecer enfranqueada.

A latere, não se resiste a notar que a ideia de Sonderverbindung desempenha ou tentou desempenhar precisamente esse papel no direito alemão - para alguns, todavia, trata-se apenas de um "Zauberwort", "ein bloßen Verlegenheitsbegriff". Cfr. Johannes Köndgen, Selbstbindung ohne Vertrag, Zur Haftung aus geschäftsbezogenen Handeln, Tübingen, 1981, pág. 90; e, ainda cepticamente, por exemplo e com referências, Dieter Medicus, Schuldrecht, I, Allgemeiner Teil, München, 2004, págs. 78 e s., frisando que, com a perda de um critério delimitador, a fronteira entre a boa fé e os boni moris se perderia.

Aponta-se mesmo a necessidade de "domesticar o monstro", de "dominar a praga". E há quem (cfr., por todos, M. W. Hesselink, The Concept of Good Faith, in Towards a European Civil Code, Kluwer Law International, 2004, págs. 486 e ss.) vá ao ponto de, com base no seu carácter "totalmente aberto" e "fluído", indicar que a boa fé deixou de constituir uma norma, apresentando um campo de aplicação ilimitado e nenhuma ou muito pouca consistência interna, tendo desaguado numa mouthpiece, num porte parole para novas normas, num mero "cover" da decisão (criativa) do juiz, num simples "pretexto" (um meio e não um fim, juntam outros), desempenhando a sua invocação uma mera "Ermächtigungsfunktion" e, por conseguinte, 
condenada, como o ius honorarium, a eclipsar-se. Um exemplo, e não dos mais flagrantes, seria o recurso à boa fé para fundar o "dever" de mitigação do próprio dano.

Fora tais excessos e inconsistências, reconhecer-se-á a (importante) "função de desenvolução" do direito que o princípio da boa fé sempre desempenhou, havendo, por isso, quem fale de uma "supra- ou super-norma", capaz de modificar outras normas ou de as criar. 0 que se pode bem documentar com certas inovações doutrinais e jurisprudenciais, sobretudo no espaço tudesco, como a da culpa in contrahendo, a do Wegfall der Geschäftsgrundlage e a do Vertrag mit Schutzwirkung zugunsten Dritten, que dela partiram. Figuras e institutos esses la par, por exemplo, do reconhecimento de deveres acessórios e laterais, e em particular de deveres de informação alargados], que entretanto, pelo menos em parte, conheceram expressa consagração legal, tornando-se assim, com a sua positivação, desnecessário a invocação ou o recurso directo ao princípio geral - a chamada "Durchgangsfunktion" da boa fé.

Sobre estes aspectos, e sobretudo quanto à necessidade de repensar a pretensão de impor a outrance, "paternalisticamente" (trata-se, no fim de contas, de proteger o próprio sujeito da sua autodeterminação) e "padronizadamente", a "justiça contratual” (e até a "justiça distributiva", cuja realização cabe precipuamente ao direito público; um "assistencialismo contratual", desconforme à lógica económica do tráfico negocial e comercial, pode aqui ver-se), culminando nalgumas conhecidas absurdidades do actual direito dos consumidores - ao abandonar-se a ideia condutora da protecção em face de efectivas desigualdades económicas e sociais - e sobretudo na peregrina ideia da generalização de semelhantes disposições, pensadas para uma relação empresa/consumidor, ao domínio lato das relações entre particulares -, mormente por apelo à ideia de boa fé e por via integrativa ou correctiva do conteúdo contratual, submetendo as partes a uma regulamentação que nenhuma realmente quis ["forçage du contrat"], ou não podendo aquelas afastarem-se da regulamentação prevista em normas supletivas (fazendo relevar, portanto, em primeira linha a função protectora do direito dispositivo], sem para isso se aduzirem "razões objectivas" e sem que o equilíbrio, em termos de vantagens e desvantagens, fique salvaguardado (cfr. a este propósito, por último, na jurisprudência comunitária, Acórdão do Tribunal de Justiça, 1 de Abril de 2004, C-237/02, Freiburger Kommunalbauten $\mathrm{GmbH}$ Baugesellschaft \& $[0 . K G$ ), tudo em detrimento da sua livre decisão, ou seja, numa fórmula sintética, a substituição do "paradigma" da liberdade contratual e da responsabilidade individual por um (hipertrofiado] "sistema de justiça negocial”, cfr., por último, Antonio Spadafora, La regola contrattuale tra autonomia privata e canone di buona fede. Prospettive di diritto europeo dei contratti e di diritto interno, Torino, 2007, passim. E já Dieter Reuter, Die ethischen Grundlagen des Privatrechts - formale Freiheitsethik oder materiale Verantwortungsethik?, AcP, 189, págs. 199 e ss.; Dieter Medicus, Abschied von der Privatautonomie im Schuldrecht? Erscheinungsformen, Gefahren, Abhilfen, Köln, 1994. Ver ainda Michael Martinek, Vertragsrechtstheorie und Bürgerliches Gesetzbuch (http://archiv. jura.unisaarland. de/projekte/Bibliothek2/text.phpid=375); Claus-Wilhelm Canaris, Verfassungs- und europarechtliche Aspekte der Vertragsfreiheit in der Privatrechtsgesellschaft, in Festschrift für Peter Lerche zum 65. Geburtstag, München, 1993, págs. 873 e ss., Id., A liberdade e a justiça contratual na «sociedade de direito privado», in Contratos: Actualidade e Evolução, Porto, 1997, págs. 49 e ss. (para a relação entre justiça e liberdade contratuais); H. Eidenmüller / F. Faust / H. C. Grigoleit / N. Jansen / G. Wagner / R. Zimmermann, Der Gemeinsame Referenzrahmen für das Europäische Privatrecht - Wertungsfragen und Kodificationsprobleme, JZ, 2008, págs. 529 e ss., especialmente págs. 535 e ss. (quanto à proliferação de cláusulas gerais, nomea- 
damente respeitantes à boa fé, e de conceitos indeterminados no DCFR). Ver ainda a obra de Jürgen Oechsler, Gerechtigkeit im modernen Austauschvertrag. Die theoretischen Grundlagen der Vertragsgerechtigkeit und ihr praktischer Einfluß, Tübingen, 1997; e a de Georg Graf, Eine Untersuchung zum Modellcharakter des vernünftigen Vertrags, Wien, 1977. E as intervenções contidas em Die ethischen Grundlagen des Privatrechts (herausg. F. Bydlinski / T. Mayer Maly), Wien, 1994.

VI. Mais concretamente e no seu conteúdo material, a boa fé representa uma pauta lou estalão) geral de conduta e de valoração de comportamentos (standard of conduct; mas também com uma "função de apelo"). Ordenando, no âmbito de uma "relação ou contacto especial" (muito latamente entendida; no fundo, será suficiente qualquer relação jurídica, todavia a "intensidade da relação" não deixará de se repercutir nos concretos ditames derivados, para aí, da boa fé e na respectiva extensão), um agir leal (segundo a "virtude da constantia"; fairness e loyauté), de "fidelidade" (lembre-se a expressão alemã Treu und Glauben), honesto ou probo (pelo menos, não desleal ou desonesto; tal como sucede para muitos outros princípios jurídicos, a sua incidência ou actuação negativa ou de exclusão, acaso proscrevendo certos comportamentos - "a excluder principle, excluding the unreasonable rather than imposing positive standards of conduct and positive duties", como o entendem os juristas da common law -, é mais "consensual"), correcto, razoável (embora a ideia de razoabilidade pareça constituir um critério de valoração mais exigente e mais próximo do caso concreto - assim, algo tautologicamente, acaso para tentar conciliar a tradição continental com o recurso à reasonableness usual na common law, Art. 1:302 PECL, e, em moldes um pouco diferentes, Art. I.-1:104 DCFR]. Reclamando uma conduta "aberta", transparente ["open dealing"].

E impondo que se salvaguarde as (legítimas) expectativas criadas ou a confiança suscitada (efectiva, e imputavelmente), ou logo que se evite causá-las. Visto da perspectiva do obrigado, proscrevendo um comportamento inconsistente, arbitrário, incoerente ou contraditório - conquanto não se possa tratar, simplesmente, de impedir que uma das partes mude de opinião -, desproporcionado. Protegendo a contraparte contra "eine unsittliche Verletzung desjenigen Zutrauens, worauf aller menschlicher Verkehrs beruht" (como já o exprimia F. C. Savigny, System des heutigen römischen Rechts III, Berlin, 1840, págs. 117 e s.). "Its purpose is to enforce community standards of decency, fairness and reasonableness in commercial transactions", lê-se por sua vez nos comentários aos PECL.

Atrás, aliás, já se aludiu à distinção entre uma componente ética, associada à boa fé, nesta surgindo em primeiro plano, e uma componente orientada pela ideia de segurança jurídica, dentro do princípio da confiança, porventura aqui tão importante como considerações materiais. Vale a pena voltar a citar Larenz, autor que - depois de indicar que o princípio da boa fé impõe que uma confiança concitada de um modo imputável deva ser mantida quando efectivamente alguém nela creu, nisso coincidirá com o princípio da confiança - sustenta que aquele ultrapassa este, vai mais além, enquanto requer ainda uma atenção recíproca, sobretudo naquelas relações jurídicas que implicam um larga e continuada colaboração; enquanto exige também o respeito do outro no exercício dos próprios direitos; e enquanto reclama, ainda e em geral, o comportamento que se pode esperar entre sujeitos que participam lealmente no tráfego jurídico. Isso não impede que se identifique no princípio da confiança uma especial manifestação [tendo adquirido uma particular densidade) do princípio da boa fé.

No dizer de C. A. Mota Pinto: "Trata-se, no fundo, de acolher a ideia de que, em certos casos, deve relevar juridicamente a confiança justificada de alguém no comportamento de outrem, 
quando este tiver contribuído para fundar essa confiança e ela se justifique igualmente em face das circunstâncias do caso concreto. Essa relevância jurídica pode levar a atribuir efeitos jurídicos a uma situação tão-só aparente, ou ficar-se, como sucederá normalmente, por criar a obrigação de indemnização pela frustração das legítimas expectativas".

A latere, não se deixará todavia de assinalar o carácter difuso e as dificuldades em "operacionalizar" a ideia da confiança, em demarcar os contornos da sua tutela jurídica, e em apreciar a sua força fundamentadora (indique-se apenas que se afigura muito duvidoso poder a responsabilidade pré-contratual fundar-se cabalmente no princípio da confiança; inviável será, à partida, basear a vinculação negocial e a eficácia dos negócios na ideia de confiança). Veja-se, quanto a isto, o que se explana no excurso final.

Continuando com a boa fé, exige esta, portanto, uma actuação respeitosa da contraparte, atenta (de consideração equânime) aos interesses e bens do outro. Pelo menos, impõe um agir não malicioso, preocupado em não lesar o parceiro ou o colocar ilegitimamente numa posição mais desfavorável (aqui se compreendendo, segundo alguns, o duty to mitigate, o dever de mitigar o dano ocorrente em caso de inexecução ou inadimplemento do contrato]. Um princípio de equivalência e equilíbrio está-Ihe também porventura subjacente, como se dará a entender. Demandando ainda (a dicotomia entre a exigência de um comportamento leal, um dever mútuo de lealdade, acaso identificado com a boa fé - embora, em rigor, esta comporte, na sua função normativa, ainda a faceta que a seguir se indica -, e a de um comportamento cooperante, um dever de cooperação, é correntemente aceite e até parece ter sido recebida em algumas leis e projectos de harmonização] um proceder cooperante e, mais concreta $e$ particularmente, transparente [propiciando inclusive informações úteis e necessárias].

Isso não é sinónimo de altruísmo ou generosidade, mas proscreverá, claro, um "imposição aviltante" ou uma "sobrevalorização totalmente desproporcionada do próprio interesse", e um comportamento meramente "oportunístico". Nesse sentido afirma E. Mackaay, Ejan Mackaay, An economic analysis of the civil law of mandate (https: //papyrus.bld.umontreal.ca/jspui/ bitstream/1866/727/1/Mackaay_EconMandate2007.doc), pág. 6: "To accommodate such an open-ended arsenal of responses to opportunism, law needs a flexible concept, which is nonetheless compatible with the rule of law. Good faith is the umbrella concept which forms the exact opposite of opportunism. To act in good faith is to abstain from opportunistic behaviour in circumstances which lend themselves to it. Opportunism is characterised in law as bad faith, or at least the absence of good faith".

Não será mesmo despropositado falar, como por vezes surge, de uma acentuação dos "valores comunitários", de uma "orientação social", em desfavor de uma conduta puramente egoística (egocêntrica) ou movida por uma (cega) "lógica confrontacional”. De uma "releitura" (do princípio da boa fé) à luz de uma referência ao interesse geral (económico e social). Isso, em parte, já explicará que o princípio da boa fé tenda a "recuperar protagonismo", se "revitalize" em situações de crise (económica ou social).

Recordar-se-á, como súmula dos pontos anteriores, a definição contida no Art. I.-1:103 DCFR: "Good faith and fair dealing (1) The expression "good faith and fair dealing" refers to a standard of conduct characterised by honesty, openness and consideration for the interests of the other party to the transaction or relationship in question. (2) It is, in particular, contrary to good faith and fair dealing for a party to act inconsistently with that party's prior statements or conduct when the other party has reasonably relied on them to that other party's detriment". Cfr. ainda, no âmbito do cumprimento negocial ou contratual, Art. II.-1:103 (onde, note-se, 
intencionalmente se usa duty e não obligation, "because of the rather vague, supplementary and all-pervasive nature of what is expected from the parties and because the ordinary remedies for non-performance of an obligation are not directly available - although they may be indirectly available if the principle of good faith and fair dealing gives rise to a tacit or implied term of a contract"] e, consagrando um dever de cooperação entre o credor e o devedor, Art. III.-1:104 (e veja-se ainda: a respeito da "anulação" do contrato no caso de "dolo omissivo", para caracterização deste, Art. II-7:205[1]; acerca da alteração judicial do contrato em que tenha ocorrido "unfair exploitation", II.-7:207; a propósito dos pressupostos da possibilidade de "variation or termination" pelo tribunal do contrato no caso de alteração de circunstâncias, III. $-1: 110$ (3)(d).

Alicerça-se porventura a boa fé (também) numa ideia ética de justiça [social] e solidariedade (e utilidade social) ou até num ideal de fraternidade (cfr. acerca dos demais elementos que se terão justaposto à ideia de lealdade, Denis Mazeaud, Loyauté, solidarité, fraternité: La nouvelle devise contractuelle, in Mélange en hommage à François Terré, Paris, 1999, págs. 603 e ss.). Ajustando-se (traduzindo), como é notado, a uma visão do direito em conformidade com a que subjaz ao Estado de Direito Social.

Para o referido vector (objectivo) de justiça material e solidariedade (contratual), sem contudo ser possível estabelecer uma linha evolutiva directa, aponta a sua raiz ou origem na bona fides (antecedida pela fides e fides bona - a "fidelidade religiosa" e a "qualidade humana", cristalizando todas as virtudes nas relações com os demais; a relação entre a fides e o bonus vir é igualmente sempre sublinhada] que de modo intenso impregnou o direito romano (o próprio direito romano clássico, assente este, por sua vez, neste ponto, no antigo direito grego]. Veja-se por exemplo a ainda actual descrição de Cicero, De Officiis, I, 23 [consultou-se

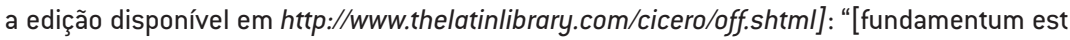
iustitiae fides, id est,] dictorum conventorum que constantia et veritas".

Constituindo aí, aliado à aequitas, já um poderoso instrumento de desenvolução do ordenamento, designadamente do sistema formulário (a importante função da boa fé explica-se como se costuma advertir, pela estrutura processual do direito romano], através das bona fide judicia. Embora sem se haver alcançado, como se deve advertir, uma noção de contrato apenas fundada no consenso.

Ver, entre outras fontes romanas, quanto ao recurso à boa fé objectiva como critério de valoração de determinadas modalidades de execução contratual e instrumento de preservação do vínculo sinalagmático, e como parâmetro para a reconstrução, realização e integração da intenção das partes, por exemplo, D. 19,1,11,1, 19,1,48, 19,1,50, 19,2,21, 44,4,1,1, 44,4,8 pr., e Gaius III,137, IV,61-63, IV,119, e Inst. 3,22,3, 4,6,28 e 30. Em geral sobre a bona fides no direito romano, cfr. introdutoriamente, com indicações ulteriores, Fondamenti di diritto contrattuale europeo. Delle radici romane al progetto dei Principles of European Contract Law della Commissione Lando, a cura di G. Luchetti / A. Petrucci / (V), Bologna 2006, págs. 38 e ss. Tem a boa fé, por outro lado, uma das suas manifestações mais precípuas no abuso do direito. Noção em todo o caso distinta, e com função própria igualmente diferente - a limitação do exercício de um direito, principalmente em atenção à finalidade da sua atribuição (mas a "confusão" entre as duas figuras poderá sobrevir, sobremodo naqueles casos em que à boa fé se adjudique uma "função correctiva"). Instituto entre nós consagrado directa e expressamente no art. $334 .^{\circ}$. Na linha do Art. 2 do ZGB suíço e do Art. 281 do Código Grego, que, mais recentemente, também o Art. 7 do Título preliminar do Código Civil espanhol, o BW neerlandês no seu 
Art. 3:13 [sem referência directa todavia à boa fé] e o Código do Québec no Art. 6 emularam. Ao contrário do que sucedia e sucede ainda na Alemanha. Aí, porém, logo após a entrada em vigor da codificação civil, o Reichgericht da mesma ideia fundamental lançou mão, prosseguindo a tradição da jurisprudência do direito comum respeitante à exceptio doli, para desenvolver as figuras da Verwirkung e da Erwirkung e para sustentar a inviabilidade, em certas situações, da invocação da nulidade resultante da inobservância da forma. Wolfgang Siebert, nos anos trinta, em Verwirkung und Unzulässigkeit der Rechtsausübung, Marburg in Hessen, Elwert, 1934, ordenaria dogmaticamente a abundante casuística existente, organizaria o vasto material jurisprudencial à volta das categorias da "Verwirkung" e do "exercício inadmissível do direito", em termos até hoje aceites. Conquanto a jurisprudência pós-guerra se haja mostrado mais comedida e se tenha polarizado na figura do venire contra factum proprium.

Tradicional é a divisão entre "abuso individual" e "abuso institucional", embora o primeiro desempenhe porventura uma função especial. Sobre tal distinção - a qual, quanto a nós, pode desempenhar uma útil função classificatória e orientadora -, cfr., apenas, J. Esser / E. Schmidt, - Schuldrecht. Allgemeiner Teil, I, Heidelberg, 1997, págs. 45 e ss.; e, entre nós, H. Ewald Hörster, A Parte Geral do Código Civil Português. Teoria Geral do Direito Civil, Coimbra, 1992, págs. 278 e ss.

Em geral, comparativamente, acerca do abuso de direito, ver, por todos, os estudos contidos no livro já citado, M. Rotondi (a cura di), L'abus de droit - L'abuso di diritto - The abuse of rights - El abuso de derecho - Der Rechtsmissbrauch, Padova, 1979.

VII. A boa fé, disse-se, domina todo o direito dos contratos (ou mais em geral o direito das obrigações por inteiro], permeia, inerva os diferentes estádios do "procedimento negocial" ["materializando-o", impondo um mínimo de equilíbrio ou justiça contratual).

Mais em pormenor, está presente no "arco jurídico" ["ciclo evolutivo", "espectro"] que vai do período de encetamento e desenvolvimento das negociações (art. 227..$^{\circ}$ ), passando pelo ciclo da conclusão (cfr. especificamente art. $224 .^{\circ},{ }^{\circ}{ }^{\circ} 2$, e art. $229 .{ }^{\circ},{ }^{\circ}{ }^{\circ} 1$ ), pela etapa do cumprimento ou execução do programa contratual (art. $762^{\circ}, n .^{\circ} 2$; para além de especiais aflorações - cfr., por exemplo, art. $524 .^{\circ}$, n. $^{\circ} 2$, e art. $802 .{ }^{\circ},{ }^{\circ}{ }^{\circ} 2$ ], até à fase pós-contratual (post contractum finitum). Interfere ainda no estádio de pendência do negócio ou contrato (art. 275..$^{\circ}$ n. ${ }^{\circ}$ 2].

Manifesta-se igualmente na qualificação, interpretação e integração dele (art. $239 .^{\circ}$ - onde expressamente se concede primazia à integração de acordo com os ditames da boa fé em detrimento da vontade hipotética das partes - e, de algum modo, art. 237. ${ }^{\circ}$, e não se exclui também que em hipóteses particulares sirva para a atribuição de valor negocial ao silêncio ou à "tolerância"; também aqui caberá a "inserção de terceiros no domínio de protecção contratual"].

Fundamenta uma anulação, modificação ou resolução, por “lesão" (cfr. arts. $282 .{ }^{\circ}$ e s.) ou por "falta ou alteração da base negocial" (cfr. arts. $252 .{ }^{\circ}$, n. ${ }^{\circ} 2$, e $437 .{ }^{\circ}$ e ss.); assim como um dever de renegociação nessas ou noutras hipóteses de modificação do equilíbrio contratual.

A que se acrescentará, com concomitante apelo ao abuso do direito, constituir o fundamento de uma restrição do direito de anulação ou da declaração de nulidade; e, contiguamente, operar na redução e conversão de negócios inválidos ou ineficazes (quando menos por recurso às regras integrativas].

Serve ainda como uma das bases (no âmbito da culpa in contrahendo, eventualmente) da 
eventual desvinculação unilateral (anulação?) por efeito da indução negligente em erro; e para a afirmação de um dever de elucidação capaz de levar à afirmação de dolo (ilícito) em caso de dissimulação do erro.

E certas hipóteses de (eventual) conexão ou coligação de contratos (e as consequências daí decorrentes] terão de ser vista à sua luz.

Em suma, percorre a formação ou surgimento do vínculo obrigacional, as vicissitudes da relação obrigacional, a própria extinção desta. Em cada um desses momentos tem porém, como se compreende, funções, incidências e manifestações diversas (e até porventura "destinatários" diferentes, nomeadamente, para além das partes, o juiz e o intérprete).

VIII. Quanto às funções (operativas] da boa fé, comece-se por recordar a proposta classificatória seminal de W. Siebert, depois (re )elaborada por F. Wieacker. Autor este último que, acerca da relação do $\S 242$ com a restante regulamentação legal, na sequência aliás de G. Boehmer, Grundlagen der Bürgerlichen Rechtsordnung, II, Tübingen, 1952, págs. 73 e s., e num paralelo - o problema fundamental de uma cláusula geral, como a da boa fé, seria o da relação do juiz com o direito escrito - com as funções atribuídas por Papiniano ao direito pretoriano, indica que tal norma (na qual, por não representar uma formatação ou modelo acabado, uma directa subsunção estaria excluída) opera iuvandi, supplendi e corrigendi gratia. Podendo, respectivamente, a boa fé ser utilizada pelo juiz:

(i) Officium iudicis, realizando o aplicador o plano valorativo do legislador, limitando-se a concretizar o projecto previamente estabelecido, planificado ou plasmado na regulamentação legal, não se tratando por isso de decidir prater legem. Isso sucederia, a mero título de exemplo, já que de algum modo todos os principais preceitos do direitos das obrigações se poderiam derivar do princípio da boa fé, na integração contratual, na consideração dos chamados naturalia negotti, na desenvolução dos deveres de protecção e das hipóteses de violação contratual positiva, e na inconsideração de "casos de insignificância" (minima non curat praetor).

(ii) Praeter legis, exigindo das partes, no exercício ou defesa dos seus direitos, um comportamento em conformidade com ditames ético jurídicos práticos. As máximas aqui em causa, pelo seu próprio fundamento à frente explicado, teriam uma validade intemporal, embora a sua realização esteja condicionada historicamente. Basicamente, haveria que referir a exceptio dolis, onde se incluiria o venire contra factum próprio (ou seja, a inadmissibilidade de um comportamento contraditório, reconduzível à ideia de "justiça pessoal", de alguma maneira enraizado na virtude da constantia, na confiabilidade das partes, aplicação, pois, do princípio da confiança], a inviabilidade de uma actuação com "falta de um interesse próprio duradouro" (raramente invocável, somente o sendo quando razões de garantia se sobrepusessem a outros valores materiais, radicada afinal na própria unidade da ordem jurídico-civil, e tendo como melhor exemplo o dolo agit qui petit quod statim redditurus est, o comportamento doloso de quem pede ou reclama aquilo que sabe que logo terá que restituir], e, finalmente, o tuo quoque (quer dizer, a "excepção de aquisição de um direito de má fé" - aglutinando uma série de conhecidas máximas, como turpitudinem suam allegans non auditur, he who comes to equity must come with clean hands, he who wants equity must do equity e o inciviliter agere, isto é, a proscrição da prossecução claramente iníqua e egoística de um direito, "grob unbilige, rücksichtlose Rechtsverfolgung" -, ancorado na "lei estrutural da comunidade jurídica", segundo a qual os próprios sujeitos de direito estabeleceriam os critérios, os standards pelos quais seriam avaliados, a sua actuação apreciada, e na própria ideia de igualdade, não se podendo 
pedir ao parceiro um tratamento mais favorável do que aquele que the foi dispensado).

(iii) Contra legem, operando através de rupturas ou brechas ético-jurídicas introduzidas pela jurisprudência no direito legal, mediante criação inovadora mas legítima (seja porque segue as "convenções adoptadas por uma jurisprudência constante", seja porque se deixa orientar pelas concepções socio-culturais reconhecidas em geral; longe, em todo o caso, de uma concretização do plano do legislador]. "Irrupções" ou "emersões" da historicidade e de novos conteúdos da consciência social geral no direito positivo. Modificação das "verdades" reconhecidas de uma maneira geral por certa cultura jurídica, passando, por força das alterações sociais ocorridas, a ter-se por injustas e inadequadas valorações até aí consideradas justas e adequadas (hipóteses estas últimas onde o cláusula geral da boa fé acabaria por preencher uma função meramente "mnemotécnica" - "§ 242 ist in dieser Funktion nur eine Geburtshilfe, gröber könnte man sagen: eine Eselsbrücke der richterlichen Rechtsschöpfung”]. Serviriam aqui de exemplo, na Alemanha, a alteração da contraprestação em razão de uma alteração supervenientes das circunstâncias económicas, para manter a equivalência do sinalagma, e a "teoria do limite do sacrifício"; ambas tendo por trás de si a emersão da exigência de uma equivalência material e de uma socialmente justa contrapartida ou contraprestação, decorrentes assim da passagem de uma ordem jurídica ou de um Estado liberal para uma ordem jurídica ou um Estado social.

IX. Muito genericamente e com óbvias sobreposições, na sequência do exposto, será possível, não perdendo de vista o direito português, discriminar as (os) seguintes principais (tipos de) funções desempenhadas pela boa fé (no domínio contratual): (i) uma função de concretização e complementação (ou, se quiser, de interpretação e integração), nomeadamente de deveres ou obrigações (patente no art. $762 . .^{\circ},{ }^{\circ}{ }^{\circ} 2$, no art. $227 .^{\circ}$ e no art. 239. ${ }^{\circ}$; a boa fé pode, como se assinala, conduzir à conformação da relação contratual, quer pela imposição de certos deveres secundários, mas também pela ampliação do dever de prestar); (ii) uma função limitativa e de controlo, nomeadamente de direitos ou faculdades (assim no art. $334 .^{\circ}$ e na regulamentação das cláusulas contratuais gerais); e (iii) uma função correctiva (corrigendi causa) ou adaptativa, transformativa ou modificativa (eventualmente libertando mesmo o devedor do seu dever de prestar, ou implicando efeitos "desvinculativos", como previsto no art. $437 .{ }^{\circ}$ - recorde-se ainda a remissão do art. $252 .{ }^{\circ}, \mathrm{n} .{ }^{\circ} 2$, para a norma citada - e no caso de "denúncia por razões ponderosas de uma relação duradoura"; também aqui se incluirão as hipóteses, mais recentemente postas em destaque, de obrigação de renegociação do contrato e do seu conteúdo].

0 que, de resto, não se afasta muito da elaboração paralela noutros países. Só a título de exemplo, em Itália, é corrente distinguir, simplesmente, entre função valorativa e função integrativa.

Nas doutrinas belga - sobretudo na sequência da conhecidíssima exposição sobre o tema de F. Baert, De goede trouw bij de uitvoerig van overeenkomsten, Rechtskundig Weekblad, 1956-57, págs. 487 e ss. - e holandesa, referem-se frequentemente, e sobretudo tendo em vista o domínio contratual, as funções de interpretação, de complementação, de limitação e de adaptação.

Recentemente na doutrina francesa, S. Tisseyre distingue uma "função procedimental", permitindo a apreciação pelo juiz da adequação do comportamento das partes, de que resultaria um dever de abstenção de uma conduta desleal e um dever positivo de cooperação; e uma 
"função substancial", ou seja, incidindo sobre o conteúdo ou extensão dos direitos e obrigações assumidas, quer num "papel aniquilador" (na formação e na execução do contrato), quer num "papel criador" (ou "completivo", mormente em matéria de interpretação e integração). E num estudo sobre a boa fé, quanto ao "acquis comunitário", divide-se a "função moralizadora" atribuída por muitos ordenamentos à boa fé em "completiva", "adaptativa" " "restritiva". 0 esquema anteriormente referido é também adoptado, no essencial e hoje em dia, pela grande maioria dos autores e pela jurisprudência na Alemanha. Onde - por referência, portanto, ao $\S 242$ BGB (desenvolvendo aquilo que já se chamou um "Código Civil paralelo", "revolucionando o direito das obrigações"; tenha-se ainda em conta o § 157 BGB, quanto à interpretação dos contratos], devendo porém notar-se que alguns desses grupos de casos se encontram agora, depois da Schuldrechtsmodernisierungsgesetz de 2002, directamente, no todo ou em parte, regulados na lei, como sucede com a culpa in contrahendo, § 311(2) e [3], com a cláusula rebus sic stantibus, $§ 313$ - "Störung der Geschäftsgrundlage" - e com a "denúncia" de um contrato duradouro, na falta de apósita convenção, ou, mais em geral, "aus wichtgem Grund", $\S 314$ - "Kündigung von Dauerschuldverhältnissen aus wichtigem Grund" -, quase sempre se acaba por dividir e ordenar a aplicação do princípio da boa fé segundo a seguinte tipologia tripartida: concretização e complementação de direitos e deveres, mais precisamente fundamentação e constituição de deveres laterais ou acessórios (abrangendo os deveres legais de protecção), ao lado dos deveres principais, no âmbito de uma relação obrigacional (aqui se incluindo os deveres pré-contratuais e pós-contratuais); negação ou limitação e restrição de direitos (ou, correspondentemente, a sua criação) no âmbito do abuso do direito ou do exercício inadmissível (venire contra factum proprium, Verwirkung - "aparência de renúncia", "laches" -, Erwirkung]; controlo e "correcção" do conteúdo desigual do negócio [ou "resolução" deste), concretamente da desigualdade ou desequilíbrio das prestações a que as partes se vincularam, plasmada na figura ou conceito da base negocial e da sua (anormal) alteração. Uma "descrição" algo diferente (fundamentalmente na ordem e na forma que não no conteúdo) encontra-se, por exemplo, em K. Larenz, Lehrbuch des Schuldrechts..., cit., I, págs. 130 e ss., autor que aponta, a propósito da concretização do princípio da boa fé, três direcções em que este se desdobra: por referência ao devedor, ao credor e aos participantes numa "Sonderverbindung". Seguidamente, alude à interferência do princípio da boa fé no que concerne: à espécie e ao modo de realização da prestação; à restrição do exercício de direitos (por parte do credor e, mais em geral, no exercício de qualquer direito: venire contra factum proprium e Verwirkung); à inexigibilidade da prestação; à "resolução ou modificação" do contrato por falta ou desaparecimento da base negocial; à fundamentação de deveres de conduta e deveres laterais ou acessórios; ao estabelecimento de deveres pós-contratuais; à constituição de deveres de prestação através da "Erwirkung"; à exceptio doli generalis em matéria processual. E considera ainda uma eventual restrição das exigências de forma através do princípio da boa fé (só admissível em situações extremas, a saber: se uma das partes impediu, dolosamente, a observância da forma; nos casos de "formlosen Bestimmung des Hoferben"; nas hipóteses em que ambas as partes conheciam as exigências de forma, tendo uma delas, pela sua situação de preponderância, demovido a outra da formalização do negócio, havendo este sido cumprido).

Cfr. ainda, entre muitos, com diferenças mais de pormenor ou de terminologia do que substanciais, Günther H. Roth, Münchener Kommentar zum Bürgerlichen Gesetzbuch, II, Schuldrecht. Allgemeiner Teil (§§ 241-432), München, 1985, págs. 97 e ss.; Olaf Werner, Handkommentar 
zum Bürgerlichen Gesetzbuch, hg. bis zu 4. Auflage von W. Ermann), I, München, 1993, págs. 506 e ss.; Joachim Gernhuber, § 242 BGB - Funktionen und Tatbestände, JuS, 1983, págs. 764 e ss.; Dirk Looschelders / Dirl Olzenm, J. von Staudingers Kommentar zum BGB, Buch 2, Recht der Schuldverhältnisse (Einl. zu §§ 241 ff, §§ 241-243), München, 2005, especialmente págs. 211 e ss.; W. Fikentscher / A. Heinemann, op. cit., págs. 114 e ss.; P. Schlechtriem / M. Schmidt-Kessel, Schuldrecht. Allgemeiner Teil, Tübingen, 2005, págs. 74 e ss.

X. Ver sobre todo o anterior, em geral, com indicações ulteriores e referências bibliográficas (que aqui seria descabido pretender tratar e enumerar exaustivamente), Salvatore Romano, Buona fede [dir. priv.], ED, V, Milano, 1959, págs. 677 e ss.; Guido Alpa, Fonti del diritto, clausola generale di buona fede, diritto giurisprudenziale, (in http://www.altalex.com/index. php?idstr=24\& idnot=6180), Id., La completezza del contratto: il ruolo della buona fede e dell'equità, in ALPA, G. / BUCCIO, E. N. (raccolti da), La Riforma dei Codici in Europa e il Progetto di Codice Civile Europeo. Materiali dei Seminari 2001, Milano, 2002, págs. 119 e ss; II ruolo della buona fede oggettiva nell'esperienza giuridica storica e contemporanea. Atti del Convegno internazionale di studi in onore di Alberto Burdese (a cura di Luigi Garofalo), I-IV, Padova, 2003; Riccardo Cardilli, "Bona fides" tra storia e sistema, Torino, 2004; II principio di buona fede (Giornata di Studio - Pisa, 14 Giugno 1985), Milano, 1987; Emanuele Stolfi, "Bonae fidei interpretatio". Ricerche sull'interpretazione di buona fede fra esperienza romana e tradizione romanistica, Napoli, 2004; T. Pfeiffer / M. Erbens, Rodolfo Sacco, La buona fede nella teoria dei fatti giuridici di diritto privato, Torino, 1949; Bigliazzi Geri, Buona fede nel diritto civile, Dig. disc. priv. (sez. civ.), IV, Torino, 1988, págs. 154 e ss.; M. Bessone / A. D’Angelo, Buona fede, Enc. Giur. Trecanni, V, Roma, 1988, págs. 1 e ss.; Good faith, in European Contract Law Materials for a Common Frame of Reference: Terminology, Guiding Principles, Model Rules [Edited by B. Fauvarque-Cosson and D. Mazeaud; prepared by J.-B. Racine / L. Sautonie-Laguionie / A. Tenenbaum / G, Wicker], Munich, 2008, págs. 150 e ss.; Studi sulla buona fede, Milano, 1975; Salvatore Romano, Buona fede (dir.priv), ED, V, Milano, 1959, págs. 677 e ss.; La regola contrattuale tra autonomia privata e canone di buona fede. Prospettive di diritto europeo dei contratti e di diritto interno (dirett. Antonio Spadafora), Torino, 2007; Giovanni Maria Uda, La buona fede nell'esecuzione del contratto, 2004; Delia M. Ferreira Rubio, La Buena Fe. El Principio General en el Derecho Civil, Madrid, 1984; Fernando Martínez Sanz, Buena Fe, in Derecho Privado Europeo Europeo. Estado Actual y Perspectivas de Futuro. Jornadas en La Universidad Autónoma de Madrid, 13 y 14 de diciembre 2007, Navarra, 2008, págs. 481 e ss. (para um breve panorama do papel da boa fé no plano dos normativos europeus, sobretudo na Directiva 93/13/CEE do Conselho, de 5 de Abril de 1993, relativa às cláusulas abusivas nos contratos celebrados com os consumidores, na Directiva 97/7/CE do Parlamento Europeu e do ConseIho, de 20 de Maio de 1997, relativa à protecção dos consumidores em matéria de contratos à distância, e na Directiva 86/653/CEE do Conselho, de 18 de Dezembro de 1986, relativa à coordenação do direito dos Estados-membros sobre os agentes comerciais); Gunther Teubner, Legal irritants: Good faith in British Law or How Unifying Law Ends Up in New Divergences (in http://www.helsinki.fi/oikeustiede/oppiaineet/kansainvalinen yksityisoikeus/materiaali/ teubner\%20legal\%20irritants2010.pdf); Christian Eckl, Treu und Glauben im Spanischen Vertragsrecht, Tübingen, 2007 (com amplas indicações sobre a doutrina e a jurisprudência espanholas); A. D’Angelo / P. G. Monateri / A. Somma, Buona fede e giustizia contrattuale. Modelli cooperativi e modelli conflittuali a confronto, Torino, 2005; La Bonne Foi (Journées louisianai- 
ses], Travaux de l'Association Henri Capitant, XLII (1992); La Confiance Légitime et l'Estoppel, Paris, 2007; Franz Wieacker, Zur rechtstheoretischen Präzisierung des § 242 BGB, Tübingen, 1956 (donde procede a resenha, muito conhecida, da gradual elaboração da tessitura ou contextura das cláusulas gerais e do respectivo conteúdo através de cada pronúncia judicial, realização de uma escolha entre várias valorações possíveis, constituindo um elemento de uma renovada criação do Direito, ou seja, um forma de law in making, pois aquelas não conteriam ou forneceriam uma "linha de decisão" pronta, havendo os valores ou valorações para os quais remetem de ser elaborados no decurso do processo de descoberta da decisão, tendo as experiências jurisprudenciais, máximas e regras - um ius commune, a que se juntarão ainda as valorações ético-sociais e os princípios da ética prática firmados -invocadas que ser actualizadas ante a concreta situação a resolver: "[...] schafft die Anwendung der Generalklausel, d.h. jede Entscheidung nach $\S 242 \mathrm{BGB}$, selbst am werdenden und kommenden Recht mit, wie der einzelne Nadelstich am Gewerbe, setzt in actu eine Linie fort, deren Richtung noch nicht vorher festgelegt sein kann"; juntando-se, particularmente no que tange à boa fé e aos bons costumes, que não se trataria de um molde acabado, o qual, simplesmente, o juiz premiria sobre o material colocado debaixo dele colocado, mas uma exigência ou tarefa única a realizar pelo próprio aplicador na situação determinada de cada caso concreto); Max Hamburger, Treu und Glauben im Verkehr, Mannheim, 1930; T. Duve / H.-P. Haferkamp, § 242. Leistung nach Treu und Glauben, in Historisch-kritischer Kommentar zum BGB, II, Schuldrecht: Allgemeiner Teil, 1. Teilband, §§ 241-304, (hg. von M. Schmoeckel / J. Rückert / R. Zimmermann), Tübingen, 2003, págs. 274 e ss. (mostrando em especial uma continuidade histórica da aplicação e elaboração da bona fides nos séculos XIX e XX); Good Faith in European Contract Law (ed. R. Zimmermann / S. Whittaker], Cambridge, 2000; Good Faith and Fault in Contract Law (ed. Jack Beatson / Daniel Friedman), Cambridge, 1995; Hector L. MacQueen, Good Faith, in European Contract Law. Scots and South African Perspectives (ed. By H. MacQueen / R. Zimmermann, Edinburgh, 1988, págs. 43 e ss.; Peter Schlechtriem, Good Faith in German Law and in International Uniform Laws, (in http://w3.uniroma1.it/idc/centro/publications/24schlechtriem); Robert S. Summers, "Good Faith" in General Contract Law and the Sales Provisions of the Uniform Code, Virginia Law review, 54 (1968), 2, págs. 195 e ss., Id., The General Duty of Good Faith - Its Recognition and Conceptualization, Cornell Law Review, 67 (1982), págs. 810 e ss.; Bénédicte Fauvarque-Cosson [dir.], La confiance légitime et l'estoppel, Paris, 2007; Sandrine Tisseyre, Le rôle de la bonne foi en droit des contrats. Essai d'analyse à la lumière du droit anglais et du droit européen, Aix-en-Provence, 2012 ; Martijn W. Hesselink, The Concept of Good Faith, in Towards a European Civil Code..., cit., págs. 471 e ss.; European Contract Law. Materials for a Common Frame of Reference: Terminology, Guiding Principles, Model Rules (ed. by B. Fauvarque-Cosson and D. Mazeaud), Munich, 2008, págs. 150 e ss., e 315 e ss.; Mario Barcellona, La buona fede e il controllo giudiziale del contratto, in I/ contratto e le tutele..., cit., págs. 305 e ss.; Brigitte Lefebvre, La bonne foi: notion protéiforme in (http://www.usherbrooke. ca/droit/fileadmin/sites/droit/documents/RDUS/volume_26/26-2-lefebvre.pdf).

XI. E, entre nós, A. Vaz Serra, Objecto da Obrigação. A prestação - suas espécies, conteúdo e requisitos, BMJ, 74 (1958), págs. 45 e ss. (com a seguinte proposta de articulado: "1. As partes podem, sempre que a isso se não oponham a ordem pública ou os bons costumes, determinar como entenderem o conteúdo da obrigação. Podem também, sob a mesma reserva, celebrar negócios jurídicos diferentes dos previstos na lei. 2. 0 devedor e o credor devem 
conduzir-se, na realização da prestação e no exercício do crédito, como a boa fé o exige. $\mathrm{Na}$ determinação da boa fé, devem ter-se em consideração os usos de negocias, onde os houver. 3. Na falta de disposição das partes, nos termos do $\S 1 .^{\circ}, 1 .^{a}$ parte, observam-se as disposições legais aplicáveis e, na ausência destas, a boa fé e as demais regras que autorizam o juiz a completar o direito. 4. A boa fé, de que nos parágrafos antecedentes se faz menção, pode conduzir também a que se admita ou exclua alguma obrigação e deve ser observada mesmo que se trate de pretensões baseadas num direito real ou de outra natureza ou que estejam em causa disposições legais imperativas, salvo se estas tiverem uma finalidade incompatível com as exigências dela. A boa fé deve ser apreciada oficiosamente pelo juiz. 6. Se, nem da vontade das partes, nem da lei, nem da criação judicial, resultar a obrigação, deve ela ser excluída; se de nenhuma daquelas fontes derivar um conteúdo mais extenso para a mesma obrigação, deve admitir-se o conteúdo menos extenso. 7. Os negócios jurídicos, de que trata a $2 .^{a}$ parte do $\S 1 .^{\circ}$, regem-se, sucessivamente, pelas disposições das partes, pelas disposições legais análogas relativas aos negócios afins, pelas disposições gerais das obrigações, pelas que o juiz criar de acordo com a boa fé e as demais regras que o autorizam a completar o direito"); J. M. Antunes Varela, Das Obrigações em geral, I, Coimbra, 1989, págs. 29 e s. e 265 e ss., Id., A Reforma do Direito Civil (no Projecto de Código Civil), Lisboa, 1966, e Id., Do projecto ao Código Civil, Lisboa, 1966; Rui de Alarcão, Direito das Obrigações, Coimbra, 1983, págs. 107 e ss.; M. J. Almeida Costa, Direito das Obrigações, Coimbra, 1991, págs. 86 e ss., e 234 e ss.; J. L. Ribeiro de Faria, Direito das Obrigações, II, Coimbra, 1990, págs. 254 e ss.; A. Menezes Cordeiro, Da Boa Fé no Direito Civil, Coimbra, 1984, passim, especialmente págs. 527 e ss. e 1234 e ss., Id., Die Dogmatisierung des Systemdenken durch Treu und Glauben, in Festschrift für Claus-Wilhelm Canaris zum 70. Geburtstag, I, München, 2007, págs. 857 e ss., e Id., A boa fé nos finais do séc. XX, ROA, 1996, págs. 887 e ss., Tratado de Direito Civil, $\mathrm{I}-1$, Coimbra, 1999, págs. 175 e ss. (o autor indica como principais institutos onde se plasma a boa fé objectiva, a culpa in contrahaendo, a integração dos negócios, o abuso do direito, a modificação dos contratos por alteração das circunstâncias e a complexidade das obrigações - adveniente esta da junção da violação positiva do contrato e da ideia da obrigação como uma estrutura complexa; e invoca como "princípios mediantes" fundamentais da boa fé, reconduzíveis afinal à ideia de igualdade, a tutela da confiança e a primazia da "materialidade subjacente", concretizada a última, por sua vez, nas ideias ou vectores da conformidade material das condutas, dando primazia ao valores pretendidos ou recebidos pelo ordenamento e não ao "ritualismo exterior", na idoneidade valorativa, presente precipuamente no dolo agit e no equilíbrio das posições jurídicas, que vedaria, por exemplo, os actos emulativos e uma actuação gravemente desequilibrada, ou seja, uma conduta que para a obtenção de uma vantagem ínfima ou pouco apreciável gere um dano relevante para outrem); L. M. Menezes Leitão, Direito das Obrigações, I, Coimbra, 2005, págs. 54 e ss.; J. C. Brandão Proença, Direito das Obrigações. Relatório sobre o programa, o conteúdo e os métodos de ensino da disciplina, Porto, 2007, págs. 143 e ss.; M. A. Carneiro Frada, Teoria da confiança e responsabilidade civil, Lisboa, 2001, especialmente págs. 431 e ss. (sobretudo quanto à relação do princípio da boa fé com a responsabilidade pela confiança).

XII. Acerca da questão da função e do conteúdo da boa fé e das cláusulas gerais e da sua concretização, ver Gunther Teubner, Standards und Direktiven in Generalklauseln, Frankfurt am Main, 1971, e Id., Kommentar zum Bürgerlichen Gesetzbuch (Reihe Alternativkommenta- 
re), II, Allgemeines Schuldrecht (§ 1-240), Luchterland, 1980, págs. 34 e ss., destacando as virtualidades das cláusulas gerais ao permitirem uma "reacção flexível do direito às mutações sociais", e distinguindo, numa tipologia das funções das cláusulas gerais e a propósito da sua concretização, uma "função de recepção" das normas sociais, uma "função de transformação", por força da qual valores, ainda não normas, seriam modelados judicialmente em regras de comportamento, e uma "função de delegação" (ou "atribuição") de funções legislativas ao juiz (já especificamente a propósito do § 242, fala de uma "função de complementação", uma "função de limitação" e uma "função de autorização"]. Para o autor, as cláusulas gerais diferenciam-se das demais normas não "prinzipiell, sondern nur gradual", pois ambas as categorias de normas constituem um modelo (de expectativas sociais de comportamentos] "não científico-social-normativo", que se caracteriza pela combinação de pelo menos três sub-modelos, um empírico ("theoretische Sätze über die gesellschaftlichen Strukturen, Funktionen und Entwicklungstendenzen des rechtlich geregelten Bereichs"], um prospectivo ["rechtliche Aussagen über Normzwecke, Ziel-Mittel-Relationen, Prognosen- und Folgenbewertungen"] e um operativo (o programa normativo em sentido próprio]. Ora, nas cláusulas gerais, "das operative Ausgangmodell relativ unbestimmt ist und die entscheidungsrelevanten Informationen vom prospektivem und von empirischen Model angeliefert werden". Tal indeterminação diria respeito a todas as três dimensões das expectativas: à dimensão material (ou seja, o "programa tipo", condicional, final e valorativo], à dimensão temporal (isto é, a possibilidade de adaptação às realidades sociais em mudança) e às dimensões sociais (quer dizer, a qualidade do consenso em que se apoia, a que grupos sociais diz respeito e qual a sua medida). E só se resolveria no acto de decisão judicial (e apenas in casu, pois doutro modo comprometer-se-ia a flexibilidade de reacção que, como aludido, tal indeterminação genérica propicia), e através de uma escolha, na qual porém o juiz não seria livre mas teria de seguir determinados critérios (estes, sim, susceptíveis de serem precisados], a desenvolver segundo o ponto de vista da "adequação social" ou da "relação de correspondência entre as estruturas jurídicas e as estruturas sociais". 0 autor acaba por diagnosticar uma metamorfose da função das cláusulas gerais: da recepção de "standards" sociais para "directivas" pouco precisas mas de cariz genuinamente jurídico.

E Franz Bydlinski, Möglichkeit und Grenzen der Präzisierung aktueller Generalklauseln, in Rechtsdogmatik und praktische Vernunft - Symposium zum 80. Geburtstag von Franz Wieacker, Göttingen, 1990, págs. 189 e ss., que indica como meios de concretização das cláusulas gerais: as valorações legais e constitucionais fundamentais; reconhecidos princípios jurídicoéticos, incluindo os respectivos sub-princípios ou sub-máximas sedimentadas judicialmente; as regras e os usos ou costumes do tráfico jurídico social; as concepções ético-sociais e valorações da sociedade, respectivamente dos participantes no círculo do tráfico jurídico em causa, enquanto não sedimentadas em regras de comportamento; a "valoração própria ou pessoal" do julgador, aspirando a uma aceitação geral e podendo conduzir a um "direito judicial". Bydlinski ensaia depois uma ordenação ou hierarquização de tais meios de concretização, e sobretudo acentua o "teste sistemático" a que está sujeito o resultado através da necessidade da averiguação da sua compatibilidade com as regras precisas da ordem jurídica e com a decisão legislativa de não produção de determinadas normas.

Por seu lado, Jürgen Schmidt, Präzisierung des § 242 - eine Daueraufgabe?, in Rechtsdogmatik und praktische Vernunft - Symposium zum 80. Geburtstag von Franz Wieacker, Göttingen, 1990, págs. 231 e ss., distingue, quanto ao § 242 e ao seu eventual carácter de norma 
ou preceito legal, três grandes grupos de teses sustentadas: as "teses da igualdade ou equiparação", que vêem em tal norma uma norma como qualquer outra, distinta porém estruturalmente na sua "redacção" como cláusula geral e no seu "grau de indeterminação"; as "teses da diferenciação", que insistem numa diferença qualitativa (porventura assente na distinção entre regras e princípios, nos termos propostos por Dworkin e Alexy, sendo os últimos fundamentalmente "imperativos de optimização"; ou vendo nas cláusulas gerais "normas institucionais", isto é, que conferem um sentido institucional a certos comportamentos, em termos próximos aos propostos por Searle, e mantendo incólume a possibilidade de fundamentação das decisões); as teses que descobrem aí contido um princípio, uma "ideia de direito", uma "ideia regulativa do valor mais elevado do direito", preenchendo a norma a função de uma "remissão" para "valores específicos" e para a sua "realização na vida em comum dentro de certa comunidade jurídica" (na formulação de Larenz). Partindo da apreciação de tais teses, o autor acaba por concluir que o preceito do § 242 BGB não precisa de ser visto como expressão de uma regulamentação, pode ser entendido como contendo várias regulamentações em função do contexto. Como "norma institucional" o § 242 BGB não teria, hoje em dia, qualquer papel; nos outros contextos assumiria, no melhor dos casos, um valor formal, mas não qualquer significado informativo material. Assim, quando se fala em "precisar" o conteúdo de semelhante norma, querer-se-á referir, nem mais nem menos, o conteúdo material precisamente ganho ou adquirido através de uma "Sachdiskussion" levada a cabo (como "tarefa permanente") pelos representantes de qualquer das teses aludidas na base de argumentos comparáveis ou similares (um "transfundo comum").

Cfr. ainda, sobre tudo isto, Horst Wilhelm Haubelt, Die Konkretisierung von Generalklauseln, München, 1978, passim; Axel Beater, Generalklauseln und Fallgruppen (Erwiderung auf Ralph Weber], AcP, 194, págs. 82 e ss.; Ralph Weber, Einige Gedanken zur Konkretisierung von Generalklauseln und Fallgruppen, AcP, 192, págs. 516 e ss.; e os estudos incluídos em Die Generalklausel im Europäischen Privatrecht. Zur Leistungsfähigkeit der deutschen Wissenschaft aus romanischer Perspektive (hrsg. von Christian Baldus / Peter-Christian / Müller-Graff), München, 2006 (com ampla indicação bibliográfica logo no início). Sobre a questão da concretização de normas, em geral, ver, por último, Anne Röthel, Normkonkretisierung im Privatrecht, Tübingen, 2004, passim. 


\section{Excurso}

A propósito da referência atrás feita à ideia da confiança, importa ainda assinalar apresentar-se ela demasiadamente ubíqua, vaga e indiferenciada (mesmo admitindo uma especificação do "Ur-Vertrauen" em geral presente nas relações sociais); supor (ou assentar) o seu funcionamento ["operacionalização"] em regras ou valores (comuns ou, precisamente, "institucionalizados pelo Direito"] prévios; não ser, por regra, a confiança em si a "razão da responsabilidade" (mesmo que constitua um pressuposto imprescindível, condição necessária ou conditio sine qua non, não será, muitas vezes, condição suficiente ou condictio per quam, isto é, a respectiva função será sobretudo delimitadora, na sua ausência excluir-se-á a responsabilidade); mostrarem-se as hipóteses que fundamentam a confiança de natureza suficientemente heterogénea e fragmentária (de varie causarum figurae fala aqui - por referência a $D .44,7,1$ pr.; cfr. ainda G. III, 8, onde significativamente se lê vel ... vel e não aut ... aut - Werner Flume, Allgemeiner Teil des Bürgerlichen Rechts. Zweiter Band: Das Rechtsgeschäft, Berlin, 1979, pág. 133); implicar o juízo sobre a necessidade e justificação da respectiva tutela a ponderação concreta das circunstâncias do caso (pois não pode, bem entendido, tratar-se de apurar tout court se alguém efectivamente confiou, nem tão pouco de a regulamentação jurídica de uma situação depender, em geral, das expectativas dos intervenientes; ademais, sempre se correrá o risco de petição de princípio, se se quiser ver na própria confiança legítima a razão da tutela jurídica: aquela é legítima e digna de tutela, porque a ordem jurídica assim o determina; a ordem jurídica estabelece por que razão e em que moldes tal confiança é legítima - cfr., apenas W. Flume, op. cit., págs. 132 e s.; Eduard Picker, Positive Forderungsverletzung und culpa in contrahendo. Zur Problematik der Haftung "zwischen Vertrag und Delikt”, AcP, 183, págs. 369 e 421; Christian von Bar, Vertrauenshaftung ohne Vertrauen. Zur Prospekthaftung bei der Publikums-KG in der Rechtsprechung des BGH, ZGR, 1983, pág. 500, e Id., Verkehrspflichten. Richterliche Gefahrsteurungsgebote im deutschen Deliktsrecht, Köln, 1980, págs. 117 e ss.); e revelarem-se tão diferentes as eventuais consequências que daí se querem derivar - para que a sua invocação "em bruto" permita avançar muito no entendimento das coisas.

Com efeito, ao contrário do que pretendem alguns autores, não se vê o que se ganhe para a compreensão da especificidade e das várias facetas de uma questão dogmática (tome-se como exemplo a da procuração aparente), o que se alcance de "afinamento discriminativo", com reconduzi-la simplesmente à tutela geral da confiança (ou da aparência) e, afinal, integrá-la num âmbito tão difuso e heterogéneo (em moldes conceptuais bonnes à tout faire).

Como sublinha ainda W. Flume, loc. cit., para o direito alemão, não existe nenhum instituto autónomo de responsabilidade pela confiança. 0 que é válido também para o direito civil português, que igualmente desconhece qualquer norma geral impondo a indemnização por comportamentos que frustrem as (legítimas) expectativas de outrem (mesmo as pontuais normas que, na Parte Geral do Código Civil, se podem mais directamente filiar em tal ideia como, por exemplo, as contidas nos arts. $81 .^{\circ}, n .^{\circ} 2,229 .{ }^{\circ}, n .^{\circ} 1,24 .^{\circ}, n .^{\circ} 2$, e porventura no art. $246 .^{\circ}, n .^{\circ} 2$-, são geralmente apreciadas como casos de responsabilidade dependente de culpa e, predominantemente, inseridas no quadro da responsabilidade pré-contratual]. Ver o que a propósito destes aspectos deixámos dito no nosso Da relevância jurídica do conhecimento, cit., págs. 60 e ss.

Sobre a "primordial" diferenciação entre o direito (e a tutela jurídica) e a confiança (como fenómeno social] merece a pena ter presentes as considerações de Niklas Luhmann, Ver- 
trauen: ein Mechanismus der Reduktion sozialer Komplexität, Stuttgart, 2000, págs. 41 e ss. Em particular, o renomado sociólogo e jurista salienta que, em muitas hipóteses conexas com o domínio contratual, o princípio ou ideia da confiança se apresenta de tal modo reformulado e autonomizado que já não desempenha, nem como Tatbestand (hipótese), nem como Geltungsgrundlage (fundamento de vigência), qualquer papel (por si). E, noutras hipóteses, a "concentração" dos diferentes fundamentos jurídicos subjacentes pela lente da protecção da confiança "hat etwas Unabgeschlossen, Zufälliges und daher Unbefriedigendes an sich" ["tem em si algo de inacabado, fortuito e, por isso de insatisfatório"]. Finalmente, por vezes tratar-se-ia meramente de um ensejo para introduzir, num domínio jurídico consolidado, novas ideias através de uma argumentação eticamente fundada, justamente através do recurso à ideia da "protecção da confiança".

Cfr. ainda sobre o anterior, em crítica a uma "pura" responsabilidade pela confiança, Johannes Köndgen, Selbstbindung ohne Vertrag. Zur Haftung aus geschäftsbezogenen Handeln, Tübingen, 1981, págs. 96 e ss. ("Vertrauen ist ein ubiquitäres, psychologisches, soziales, und juristisches Phänomen" - "a confiança é um fenómeno jurídico ubíquo, psicológico e social”), especialmente pág. 102 (em apreciação das ideias de Canaris). De resto, ao próprio pensamento de Köndgen se poderá dirigir um reparo semelhante. Assim, exactamente, em recensão à obra de J. Köndgen a que nos referimos, Ernst $A$. Kramer, Johannes Köndgen: Selbstbindung ohne Vertrag. Zur Haftung aus geschäftbezogenen Verhalten [sic] (Tübinger rechtswissenschaftliche Abhandlungen, Bd. 53), Tübingen, J.C.B. Mohr, 1981, XIV, AcP, 182 (1982), págs. 469 e ss. Assinalar uma escala (ou mesmo um eventual continuum) que vai da vinculação negocial (assente numa vontade dirigida aos efeitos], passando por uma "autovinculação quase-contratual", até ao âmbito delitual, não invalida a viabilidade e a necessidade de assinalar "marcos" dentro desse espaçoso terreno. Isso precisamente faz a lei, desde logo, ao demarcar o domínio ou "estatuto" negocial (com base na necessidade de consenso) e os efeitos próprios que dele decorrem. Sem que tal signifique prescindir de sancionar ou atribuir relevância (mas em termos diferentes; normalmente confinados ao interesse negativo] a "auto-vinculações quase-negociais".

Críticas semelhantes (algumas não menos certeiras) ao "princípio da confiança" encontram-se no estudo já citado de Eduard Picker, Positive Forderungsverletzung und culpa in contrahendo. Zur Problematik der Haftung "zwischen Vertrag und Delikt”, AcP, 183, págs. 369 ss. Eem Christian von Bar, Verkehrspflichten. Richterliche Gefahrsteuerungsgebote im deutschen Deliktsrecht, Köln, 1980, especialmente págs. 221 e ss.

Por último, mais especificamente a propósito dos deveres de informação, Andre Pohlmann, Die Haftung wegen Verletzung von Aufklärungspflichten. Ein Beitrag zur culpa in contrahendo und zur positiven Forderungsverletzung unter Berücksichtigung der Schuldrechtsreform, Berlin, 2002, págs. 22 e ss. Onde se assinala, na esteira de Frotz, Flume e Picker, que os deveres de informação pré-contratual (para o autor, estes têm um lugar à parte dentro dos deveres de protecção, só eles pertencendo em rigor ao domínio contratual, enquanto os demais deveres se integrariam no domínio delitual, e apenas os deveres de informação conexionados com a conclusão do contrato, servindo directamente a protecção da liberdade negocial, se baseariam na relação obrigacional pré-contratual, pertencendo os outros, dirigidos ao "Integritätsinteresse", igualmente ao domínio delitual; os deveres de informação contratuais teriam a sua fonte no acordo negocial - enquadramento que o autor justifica por recurso às regras do Auftrag e do Geschäftsbesrgungsvertrag, em especial aos $\S \S 665$ e 666 BGB -, não desem- 
penhando aqueles cuja violação conduziria à indemnização do interesse contratual positivo praticamente qualquer papel - em concreto, no caso de violação de deveres relacionados com a conclusão do contrato seria preciso que o lesado provasse que se tivesse ocorrido o esclarecimento devido teria sido concluído um outro e mais favorável contrato com o obrigado, exceptuando as hipóteses em que a lei impõe uma estrita "Garantiehaftung"] não podem, em geral, ser fundamentados com o argumento de que já as negociações os imporiam, pois, precisamente, tais deveres apenas podem surgir no âmbito das negociações - o que não fornece ainda a sua razão de ser. Por conseguinte, incorrerá numa petição de princípio quem identifica na ideia de confiança o seu fundamento: a confiança em causa é justamente própria das negociações, pelo que, desse modo, apenas se descreve a situação em causa. A concretização da confiança numa situação determinada não representaria, quase nunca, mais do que uma mera consequência (e não a "fonte") da violação do dever, e portanto não poderia servir para fundamentar ou avaliar um comportamento anterior. Restaria o recurso à "confiança geral", a confiança em que o parceiro se comportaria de modo correcto e leal. Mas então cair-se-ia de novo num círculo vicioso: a confiança é merecedora de tutela porque a ordem jurídica a considera legítima, porque a ordem jurídica tutela a confiança ela é legítima. Além disso, a confiança estaria presente em todas as situações de responsabilidade (não seria qualquer característica específica da responsabilidade pré-contratual); ao se prescindir de tal referência (à confiança) nos domínios da responsabilidade contratual e delitual, isso indiciaria que a confiança seria irrelevante do ponto de vista da fundamentação (dogmática) da responsabilidade. $E$ não se poderia sequer dizer que a fase pré-contratual fosse em regra dominada pela confiança lao invés, imperaria uma "salutar desconfiança", desde logo pelos interesses diametralmente opostos que em geral prosseguem as partes].

Por cá, em paralelo com a doutrina alemã indicada, ver Jorge Ferreira Sinde Monteiro, Responsabilidade por conselhos, recomendações ou informações, Coimbra, 1989, págs. 488 e ss.; e Carlos Ferreira de Almeida, Texto e Enunciado na Teoria do Negócio Jurídico, Coimbra, 1992, págs. 35 e ss. e 50 e ss.

Faça-se ainda uma (imprescindível) recensão (melhor, referência; e necessariamente insuficiente por demasiado sintética), quanto à sistematização e pressupostos, parte geral, da protecção ou da responsabilidade pela confiança, da obra seminal de Claus-Wilhelm Canaris, Die Vertrauenshaftung im deutschen Privatrecht, München, 1971, passim, especialmente págs. 490 e ss. 0 emérito professor alemão, que procede indutivamente a partir do material do direito (civil) tudesco, a que dedica a primeira metade, a parte especial, da obra, exclui à partida da sua investigação os casos em que a confiança não representa a razão fundamentadora da responsabilidade: sejam as hipóteses de "absoluten Verkehrsschutz", onde a lei "firma" em absoluto uma situação jurídica duvidosa ou apenas aparente, protegendo até quem esteja de má fé; sejam aqueles casos onde a ideia da protecção da confiança ou do tráfico desempenha um relevante papel, mas in concreto os efeitos não supõem a presença de uma correlativa confiança (designadamente os efeitos da aparência independeriam da vontade de quem confia, como seria característico da "verdadeira" responsabilidade pela confiança-com efeito, segundo o autor, decorrendo do sentido e objectivo da tutela da confiança, os efeitos a ela associados apenas operariam em benefício daquele que confiou e estariam dependentes, em princípio, da sua vontade); sejam aquelas situações onde a ideia da protecção da confiança apenas assume um relevo auxiliar (porventura, o de um "mero" elemento da responsabilidade]. Deve ainda assinalar-se que se aborda na obra aqui resumida a responsabilidade 
pela confiança da perspectiva da fundamentação do dever (indemnizatório] daí emergente, deixando de lado outros efeitos, por exemplo a perda de direitos, como sucede ao originário proprietário na hipótese de aquisição a non domino.

Começa Canaris por diferenciar - naquilo que denomina de "sistematicamente constitutiva" "Zweispürigkeit" ["duplicidade", "dupla via"] da responsabilidade pela confiança-, por um lado, correspondendo às situações em que a protecção do tráfico jurídico assume papel decisivo, a "positive Vertrauenschutz" ["a protecção positiva da confiança"], uma "Anspruch auf Vertrauensentsprechung", ou seja, uma pretensão a que tenham lugar os efeitos jurídicos associados à "real ocorrência" da suposta situação; e, por outro lado, traduzindo uma predisposição individualizadora, a "negative Vertrauenschutz" (a protecção negativa da confiança"), a indemnização do "dano de confiança", sendo quem confiou colocado na posição em que estaria se conhecesse a situação real e, por isso, não tivesse confiado. Debruçando-se de seguida sobretudo sobre as primeiras hipóteses, as quais de algum modo ocupariam um lugar proeminente (mas o ilustre professor não deixa de notar que a "via indemnizatória" permitirá uma maior diferenciação e "justiça do caso concreto", até pela eventual ponderação da conculpabilidade, falando mesmo de uma sua "superioridade ético-jurídica"]. Aí pertenceriam ex definitione a "responsabilidade pela aparência" (cujo "minimal Tatbestand", a "hipótese ou factispecies mínima", é retratado do seguinte modo: quem cria conscientemente uma "Rechtsschein", "aparência jurídica", ou não a suprime, tem de se deixar tratar, em face de terceiro de boa fé, como tal aparência correspondesse à realidade], servindo a realização dos fins e necessidades do tráfico jurídico, os quais porém se mostrariam diferentes no direito civil e nos demais ramos de direito privado (lembrar-se-á, nomeadamente, que Canaris recusa a "Anscheinvollmacht" para o direito civil mas a defende no direito comercial). Ao lado desta, investiga a "Vertrauenshaftung kraft rechtethischer Notwendigkeit" ["responsabilidade pela confiança por força de uma necessidade jurídico-ética"], em realização do princípio da boa fé (que aqui não operaria apenas como fundamento de uma "excepção", mas antes como base de uma "Erfüllungsanspruch", "pretensão de cumprimento"; esta última porém só surgiria se a situação actual daquele que confiou se mostrasse "irreversível"). Mas discute também, agora claramente dentro do "negative Vertrauensschutz", a "Erklärungshaftung" ["responsabilidade pela declaração"), onde alguém tem de responder por uma declaração "defeituosa", como ocorreria, típica e concretamente, no caso de erro ou de afirmação de poderes de representação desconhecendo o procurador que não os possui, e, em geral, nalguns eventos de culpa na formação dos contratos. Noutras hipóteses de culpa in contrahendo, tratar-se-ia antes, mas assumindo a ideia da confiança ainda um papel decisivo, de uma "Anvertrauensschutz", que serviria a função de compensação de danos sofridos em determinados bens jurídicos expostos (nesse sentido, "anvertrauen"] à eventualidade ou possibilidade de imiscuição de outrem, no âmbito do tráfico jurídico-negocial.

$\varepsilon$ posto igualmente em relevo que as variegadas hipóteses de responsabilidade pela confiança, só são explicáveis dentro de uma "sistema móvel", se conjugam e complementam. Nomeadamente, uma "responsabilidade pela aparência" nem sempre seria viável por faltar uma "situação de aparência objectiva", seja porque a situação real é objectivamente reconhecível, seja porque o substrato da confiança se reporta a uma situação futura, seja porque se confia numa situação material, não jurídica, seja porque a "base de confiança" não assenta num comportamento daquele que por ela responderá(ia). Também a própria imputabilidade poderia estar em causa, designadamente se ocorresse na criação da base de confiança uma 
falta ou vício de vontade.

Mais em concreto quanto aos pressupostos da responsabilidade pela confiança (fundamentalmente no domínio da "responsabilidade pela aparência" e da responsabilidade "kraft rechtethischer Notwendigkeit"], primeiramente seria necessária uma situação objectiva que representasse a "base da confiança", o "Vertrauenstatbestand", pois uma "confiança cega" não poderia ser protegida. Procede de seguida o autor neste âmbito a várias distinções. Designadamente entre, por um lado, "künstliche Tatbestände", "factispecies artificiais", ou seja, tendo na base a lei ou por esta estabelecidas como ponto de partida da protecção da confiança, v.g., o registo ou o "Erbschein" ["certificação de herdeiro"] -, e, por outro lado, "natürliche äussere Tatbestände", "factispecies naturais exteriores", isto é, declarações verbais, documentos ou comportamentos concludentes (assim sucederia na "Duldungsvollmacht", "procuração tolerada", onde, como nos demais casos da mesma categoria, se trataria de um "schwächer Tatbestand", uma "factispecies débil ou fraca", por comparação com declarações expressas, havendo então que fazer exigências suplementares quanto à sua concludência, por exemplo a repetição da "tolerância"; todavia, admitir-se-ia que o próprio silêncio desempenhasse tal papel], onde de resto seriam chamadas a intervir as regras da interpretação das declarações negociais (sendo decisivo a perspectiva do declaratário, segundo a boa fé). Consoante o "Vertrauenstatbestand" consista numa preexistente situação ou numa situação só a ocorrer no futuro (aqui não se poderia exigir qualquer aparência mas apenas uma probabilidade). Conforme a confiança se dirija a uma situação juridicamente possível ou impossível (onde só muito, muito excepcionalmente se poderia admitir uma "Erfüllungsanspruch"]. Em função de o "Vertrauenstatbestand" se referir a uma relação jurídica ou a um facto natural. No que toca a quem é dirigida a confiança ou a concita, o que se traduziria sobretudo na questão da imputabilidade. Importando ainda a duração da "situação de confiança" e as possibilidades da sua remoção.

Depois, do lado da pessoa que confia (e a confiança pode bem não ser consciente), exigir-se-ia boa fé (subjectiva), isto é, em geral, que a pessoa em causa ignorasse (e apenas o conhecimento efectivo relevaria, excluindo a protecção, nos "kunstliche äussere Tatbestände", "factispecies artificiais exteriores", como nas hipóteses do registo e da "responsabilidade pela confiança em razão de um comportamento doloso"] ou não devesse conhecer (nos casos de "Rechtsscheinshaftung", "responsabilidade pela aparência jurídica", fora os já referidos, o "dever de conhecer" suporia especiais circunstâncias que motivassem uma desconfiança, dado relevar em primeira linha a protecção do tráfico jurídico] a incorrecção do "Vertrauenstatbestand" ou a verdadeira situação material ou jurídica.

Além disso, requerer-se-ia que a confiança efectiva se relacionasse com a "situação de confiança", o que imporia pelo menos o conhecimento desta (como aludido, uma "confiança cega" não merece ser protegida). Insuficiente mostrar se-ia porém uma mera "innere Gefühlsregung" ["impulso ou comoção interior"]. Haveria de ocorrer uma "disposição" ou "investimento de confiança", objectivando ou exteriorizando a confiança depositada. 0 investimento demandado seria todavia diferente consoante as várias hipóteses, bastando nalgumas (na "Rechtsscheinshaftung" e na "responsabilidade em razão de um comportamento doloso"] a simples (o mero incentivo à) conclusão de um negócio (e poderia mesmo aquele ser dispensado nos negócios unilaterais realizados em face da pessoa que confia), noutras tudo dependendo da sua "medida" ou "extensão" (assim aconteceria nas hipóteses de responsabilidade com base num "comportamento contraditório" ou na "Erwirkung", onde normalmente a via 
indemnizatória se revelaria satisfatória, exceptuados os casos em que aquele que confiou se adaptou e se "comprometeu existencialmente" com a situação putativa; notar-se-á que nestas últimas situações se teria por suficiente uma forte probabilidade de que o investimento de confiança haja sido suscitado pelo "Vertrauentatbestand", sem prejuízo todavia de se admitir prova em contrário].

Por outro lado, exigir-se-ia uma conexão causal entre a confiança e a "disposição", só assim sendo aquela digna de protecção. 0 que todavia não se confundiria com o conhecimento da situação base da confiança. Trata-se agora de saber se a pessoa em causa também se teria comportado do mesmo modo se conhecesse o real estado; no entanto, aqui haveria que admitir [como sucede, e com base nas mesmas razões, quanto à boa fé] uma presunção de que tal não teria sucedido.

Por último, o processo ou modo de aquisição deveria mostrar-se digno de protecção, o que não seria, nomeadamente, o caso quando a respectiva pretensão ou título não se baseasse num negócio, ou se tratasse de uma aquisição a título gratuito.

Acima de tudo, critério decisivo (que aliás assume, conforme Canaris nota, relevância bastante para além deste domínio], a responsabilidade pela confiança assentaria, no essencial, na (ideia de) imputabilidade (exceptuados os casos de "pura aparência jurídica"). E esta orientar-se-ia aqui, em geral lo argumento é sobretudo o da "Schutz des Dritten aufgrund der Verkehrsfreudlichkeit der Rechtsscheinshaftung", "protecção do terceiro pela 'benignidade' para o tráfico jurídico da responsabilidade pela aparência"], pelo "princípio do risco" ["repartição do risco por esferas"). Todavia, este careceria de concretização (para além de ter de ser entendido como elemento de um sistema móvel), sobretudo quanto a saber que riscos ou perigos estão em causa e que pontos de vista são decisivos para a sua repartição (por exemplo, Canaris indica que, no caso de a parte ter o conhecimento positivo do carácter de "Scheintatbestand" da situação, ela responderá sempre]. Como critérios concorrentes poderiam indicar-se o "Veranlassungsprinzip", "o princípio da causação" - o qual representaria, pelo menos neste contexto e no fim de contas, como uma simples "responsabilidade causal", a renúncia ao pressuposto da imputação. E o "Verschuldensprinzip", "princípio da culpa" que não se conciliaria bem, sendo até "systemwidrig" ["em contradição com o sistema"], no seu relacionamento, com a finalidade primária da "responsabilidade pela aparência", isto é, com a protecção "abstracta ou generalizante" do tráfico jurídico, mas que assumiria um papel dominante quando se trate de uma "Vertrauenshaftung kraft rechtethischer Notwendigkeit" [segundo o princípio da boa fé].

Aludidos estes aspectos gerais, e um pouco na sequência deles, faça-se ainda uma alusão às relações entre a responsabilidade pela confiança, por um lado, e a teoria do negócio jurídico e o princípio da autonomia privada, por outro, partindo do modo com as concebe Canaris.

Na obra que vimos citando (sobretudo págs. 411 e ss. e 440 e ss.), adverte-se especialmente para o risco de se resvalar para aporias, de se incorrer em contradições com o princípio da autonomia privada, embora se acentue o carácter autónomo da responsabilidade ex confiança e se insista no seu carácter complementar à auto vinculação negocial. Do mesmo autor, em geral, ver ainda, sobre as contradições valorativas e de princípios dentro do sistema jurídico, Systemdenken und Systembegriff in der Jurisprudenz, entwickelt am Beispiel des deutschen Privatrechts, Berlin, 1983 (edição de que há tradução para português de A. Menezes Cordeiro), especialmente págs. 112 e ss. Nessa obra (sobretudo págs. 93 e ss.) previne-se expressamente que nem todos os "princípios materiais" fazem parte ou se incorporam na ordem 
jurídica (num concreto ordenamento]. Desde logo, a sua "vigência" pode estar excluída ou francamente restringida através das valorações contidas no direito positivo (além disso, a necessária concretização, e mais ainda a sua "sedimentação" num instituto jurídico, do princípio em causa também quase sempre apenas se poderá fazer em estrita colaboração com o direito positivo] ou colidir com outros princípios, porventura de "grau superior". Mas mesmo que o direito em vigor não os exclua, eles não possuem, como tais, o carácter de (imediatas] fontes de direito. Há ainda, para cada um, que fundar positivamente, indicando uma especial "razão", a respectiva "vigência" e "pretensão de eficácia". Onde avultarão três possibilidades: a sua recondução à própria ideia de direito; a sua obtenção a partir da natureza das coisas; elou a conclusão de que o princípio em causa, enquanto ideia ou concepção ordenadora ou valorativa (axiológica), é imanente ao direito positivo, conquanto esteja neste apenas corporizado ou traduzido de modo incompleto.

Aos olhos de Canaris, reatando a exposição das ideias expostas no Vertrauenshaftung..., cit., e no que mais nos interessa, a vinculação negocial, o seu fundamento - a autonomia privada - e os correlativos efeitos, bem se distinguem da ideia e da responsabilidade pela confiança (haveria mesmo que preservar a teoria do negócio jurídico da imiscuição de elementos estranhos, embora não se devesse excluir que a responsabilidade pela confiança possa desempenhar um papel, secundário ou subalterno no entanto, no domínio dos negócios que padeçam de algum vício ou falta de vontade ou na impossibilidade originária objectiva ou subjectiva]. A primeira assenta, afinal, na vontade das partes e pressupõe a consciência da declaração. $A$ segunda ocorre ex lege. 0 problema é antes o de conciliar a responsabilidade pela confiança (principalmente quando esta se consubstancia numa "Erfullungsanspruch") com o princípio da autonomia privada. Necessidade que aliás se insinua na tentativa de "explicações negociais" daquela ou de algumas das suas manifestações. A este propósito (impossibilidade de integrar a responsabilidade pela confiança no domínio negocial), haveria porém que manter a distinção entre "konstitutive Erklärung", "declaração constitutiva" - pressuposto essencial para a existência de um negócio, e pela qual uma determinada "regulamentação" "é posta em vigor" - e "deklaratorische Erklärung", "declaração certificativa ou assertiva" (onde cabem justamente a "Kundgabe einer bereits erteilten Vollmacht", nos termos do § 171 BGB, e a "Duldungsvollmacht"] - a qual remete para tal regulamentação negocial, mas é insusceptível de ser explicada com recurso à teoria do negócio jurídico.

Se em termos abstractos não existe, para Canaris, uma aporia entre a responsabilidade pela confiança (mesmo que desta se venham a retirar efeitos equivalentes aos efeitos negociais] e o princípio da autonomia privada, pois este último não se poderia absolutizar nem deteria qualquer exclusividade, e aquela seria, por sua vez, reconduzível à ideia de imputação e, desse modo, ao princípio da auto-responsabilidade, não deixa o autor de reconhecer que na prática (quanto ao regime) há que evitar eventuais contradições valorativas e assegurar um relacionamento "pacífico". Isso mesmo se documenta na questão de saber se as disposições sobre os negócios são aplicáveis à responsabilidade pela confiança. Questão que o autor examina com detalhe defendendo a possibilidade de uma aplicação analógica. Assim, nomeadamente, quanto ao problema da imputabilidade, pois também na responsabilidade pela confiança se trata da participação no tráfico jurídico; no concernente às disposições sobre falta e vícios da vontade (atrás aludimos à questão da eventual anulabilidade do "Rechtsschein"], pois que uma declaração negocial não constitui um mais fraco "Vertrauenstatbestand" do que uma "deklaratorische Erklärung" (excepção feita a negócios que representam a 
base de outros ulteriores a realizar com um número indeterminado de pessoas, onde a ideia da protecção do tráfico jurídico teria proeminência); no que respeita à imputação da actuação de um terceiro, podendo recorrer-se às regras da representação e da "ratificação"; e acerca das disposições sobre a contrariedade do negócio ou do seu objecto à ordem pública ou aos bons costumes, as quais não deveriam poder ser contornadas ou goradas pela afirmação da responsabilidade pela confiança (a mesmo problemática está aliás presente quanto aos preceitos sobre a forma]. Cfr. ainda do mesmo autor, a este propósito, Die Bedeutung allgemeiner Auslegungs- und Rechtsfortbildungskriterien im Wechselrecht - Zugleich eine Besprechung der Urteil des BGH vom 26.5.1986 II ZR 260/85 und vom 27.10.1986 II ZR 103/86, JZ 1987, págs. 543 e ss., JZ, 1993, págs. 377 e ss.

Passando agora à doutrina nacional, em boa parte tributária do pensamento de Canaris, acerca da "teoria da confiança", cfr. os trabalhos fundamentais de J. Baptista Machado, Tutela da confiança..., cit., págs. 229 e ss., Id. A cláusula do razoável..., cit., págs. 65 e ss.; Menezes Cordeiro, Da Boa Fé..., cit., especialmente págs. 527 e ss., 1234 e ss., e 1252 e ss., Id., Tratado de Direito Civil, I-1, Coimbra, 1999, págs. 175 e ss. e 184 e ss.; Carlos Ferreira de Almeida, Contratos, I, Conceito, fontes, formação, Coimbra, 2008, págs. 219; e Manuel A. Carneiro da Frada, op. cit., especialmente págs. 345 e ss. e 827 e ss., Id. A responsabilidade pela confiança nos 35 anos do Código Civil - Balanço e perspectivas, in Comemorações dos 35 Anos do Código Civil..., cit., IIl, págs. 285 e ss.; e ld., Die Zukunft der Vertrauenshaftung oder Plädoyer für eine "reine" Vertrauenshaftung, in Festschrift für Claus-Wilhelm Canaris zum 70. Geburtstag, I, München, 2007, págs. 99 e ss.

Quanto aos pressupostos gerais da protecção da confiança, menção especial merece, evidentemente, A. Menezes Cordeiro, Da Boa Fé no Direito Civil, loc. cit. Como requisitos (decantados das "previsões legais específicas e das consagrações jurisprudenciais dos institutos genéricos") gerais (mas por vezes dispensados em previsões especiais) da protecção da confiança, este autor aponta os seguintes: uma situação de confiança, expressa em regra na boa fé subjectiva; uma justificação para essa confiança, pela presença de elementos objectivos na origem de uma crença razoável ou plausível (a que aderiria uma pessoa normal); um investimento de confiança, traduzido num "assentar efectivo de actividades jurídicas sobre a crença consubstanciada" (não bastando, pois, uma "puramente interior" adesão); e a imputação da situação de confiança a quem é afectado pela correspondente tutela (a sua oneração implicaria que tal sujeito fosse responsável pela situação fabricada). Tais pressupostos articular-se-iam nos termos de um sistema móvel, não existindo entre eles uma hierarquia definida, nem se revelando qualquer deles absolutamente imprescindível.

Por seu lado, Carlos Ferreira de Almeida, loc. cit., naquilo que diz constituir uma "adaptação pessoal" dos ensinamentos de Baptista Machado, Menezes Cordeiro e Canaris, enuncia os seguintes elementos que, em geral, deveriam coexistir para a tutela da confiança (esta representaria, de resto, o critério comum para verificar se, em concreto, quem invoca a violação dos ditames da boa fé merece protecção): uma situação de confiança efectiva e imputável a determinada pessoa (imputação da confiança); justificação da confiança suportada por dados objectivos e credíveis; investimento de confiança, causado por esta e traduzido em actos concretos e externos, com ou sem expressão financeira imediata; boa fé de quem confiou. Junta que neste último requisito se exige boa fé tanto em sentido subjectivo (crença no comportamento alheio) como em sentido objectivo (comportamento próprio isento de violação dos deveres de boa fé): "este segundo aspecto corresponde a uma máxima da equity (he who 
comes into equity must come with clean hands], que se pode assim transpor para o direito português: quem invoca a boa fé deve estar também de boa fé".

Por fim, há-de assinalar-se que os estudos atrás referidos de Carneiro da Frada representam, entre nós, provavelmente a tentativa mais conseguida e burilada para "depurar" o conteúdo e âmbito da responsabilidade pela confiança, procurando estabelecer e salvaguardar a sua autonomia (conceptual e de regime). Resumindo o pensamento do autor ao mais essencial [com a certeza de se ofuscarem aspectos importantes], tal desiderato implicaria a demarcação daquelas hipóteses onde a confiança é o fundamento ou razão da responsabilidade, seu pressuposto constitutivo e imprescindível ("o modelo de uma 'pura' responsabilidade pela confiança"; o autor atribui, consequentemente, à exigência corrente de uma "ligação especial" apenas um função delimitadora). E não estaria aqui em causa qualquer confiança típica ou normativa, mas uma "confiança fáctica" ou "subjectiva" (podendo todavia ser objecto de presunção].

Depois, a responsabilidade pela confiança deveria estremar-se do princípio da boa fé - este exprimiria determinadas exigências de natureza ético-jurídica que se colocam ao comportamento dos sujeitos, já a necessidade de respeitar expectativas alheias não relevaria senão enquanto manifestação de um civiliter agere -, e da responsabilidade fundada na violação de um dever aquiliano ou obrigacional - onde a frustração de expectativas não é determinante, antes sim a infracção da regula agendi. Sediando-se ela numa "quarta via ou trilho" entre a responsabilidade delitual e a responsabilidade contratual, a par da responsabilidade por violação de deveres decorrentes da boa fé no âmbito de uma relação especial.

$\varepsilon$, continua o nosso autor, derivando em termos gerais da iustitia commutativa, como responsabilidade, de índole compensatória, por um facto (não uma mera omissão) em princípio lícito (abstraindo desde logo da violação de um dever). "A responsabilidade pela confiança protege a coordenação de condutas entre os sujeitos; reconhece e implica uma noção de causalidade vinculada ao agir e à prudência humana, apresentando-se os seus requisitos como tradução jurídica da razão prática daquele que se autodetermina e das suas exigências; a noção de 'ligação especial', enquanto instrumento dogmático operativo da responsabilidade pela confiança, está também vinculada a este entendimento".

Sendo uma responsabilidade objectiva, abstraindo portanto da culpa. Dirigida em primeira linha à protecção negativa da confiança, à defesa do status quo e não à prossecução do status ad quem, ao ter como função somente a protecção do "investimento de confiança", embora abrangendo os danos emergentes e os lucros cessantes, não constituindo uma indemnização por inadimplemento, perante a inexistência de um vínculo obrigacional. Nota ainda Carneiro da Frada que em certos casos seria mesmo inviável uma protecção positiva in natura, o que permitiria explicar a falta de correspondência entre um título de imputação mais intenso (por exemplo, a existência de culpa na responsabilidade pré-contratual, por confronto com a imputação objectiva ou a título de risco no venire contra factum proprium] e uma consequência menos gravosa, isto é, uma "mera" obrigação de indemnizar - assim, por razões de coerência, haveria ainda que reconhecer uma responsabilidade indemnizatória por um comportamento contraditório a não ser possível ou justificável uma protecção positiva. Por outro lado, admitir-se-iam desvios em relação a uma tutela meramente indemnizatória, quando exista para isso uma particular justificação, quando uma tutela qualificada do tráfico o imponha ou a justiça o reclame terminantemente.

Ademais, a responsabilidade por frustração de expectativas incluiria, numa "dupla via" ou 
"dualidade interna", aliás reflectindo a própria "estruturação da realidade de coordenação de condutas, num plano prévio ao da juridicidade", quer a responsabilidade pela confiança em declarações, quer a responsabilidade pela confiança numa conduta futura.

Por fim, quer ver-se nos regimes dos arts. $245 .{ }^{\circ}, n .^{\circ} 2,229 .{ }^{\circ}, n{ }^{\circ} 1,898^{\circ}$ e $908 .^{\circ}, 81 .^{\circ}, n .^{\circ} 2$, $1172 .^{\circ}, 1594 .^{\circ}, n .^{\circ} 1$, afloramentos ou vestígios da responsabilidade pela confiança no direito civil português. E advoga-se, para um futuro próximo, a consagração positiva de uma cláusula geral contendo os pressupostos e parâmetros de aplicação de tal forma de responsabilidade. 
